\title{
PERTANGGUNGJAWABAN PIDANA DIREKTUR PERSEROAN TERBATAS DALAM TINDAK PIDANA KORUPSI PROYEK TERBATAS DALAM TINDAK PIDANA KORUPSI PROYEK PEMBANGUNAN RUMAH SAKIT (STUDI PUTUSAN NO.15 /PID.SUS- TPK/2018/PN.MDN)
}

\author{
Marthin Simangungsong', Herlina Manullang', Tulus R.G. Purba ${ }^{3}$ \\ ${ }^{1}$ Program Studi Ilmu Hukum \\ ${ }^{2}$ Program Studi Magister Hukum \\ ${ }^{3}$ Program Studi Ilmu Hukum \\ Universitas HKBP Nommensen, Medan-Sumatera Utara-Indonesia \\ e-mail: marshim61@gmail.com
}

\begin{abstract}
The existence of corporations in the Criminal Code provisions that currently apply has not clearly stipulated corporations as perpetrators of crime because only Article 59 of the Criminal Code still regulates corporate provisions. However, the provisions of regulations outside the Criminal Code have clearly regulated the existence of corporations as legal subjects such as Law Number 40 of 2007 concerning Limited Liability Companies. Corporate criminal crime in its development has been widespread in people's lives, this can be done by the management of the corporation itself. The form of corporation in its development is in the form of legal entity and non-legal entity, one of which is a legal entity is a Limited Liability Company, in Article 82 of the Company Law Director is the management of the company, the Director represents the Limited Liability Company in and out of Article 82 of the Company Law. As for the problem in this research is how the criminal responsibility of the Director of a Limited Company in a criminal act of corruption in a hospital development project (study of decision number 15 / Pid.Sus-TPK / 2018 / PN.Mdn)

The legal research method used in this study is a type of normative legal research that is research used by searching or analyzing and analyzing library materials, one of which is Decision No. 15 / Pid.Sus-TPK / 2018 / PN.Mdn. Then based on the results of research on Decision No. 15 / Pid.Sus-TPK / 2018 / PN.Mdn it can be concluded that based on the deeds and errors of the Director of PT. Care Indonusa has fulfilled the element of error, criminal liability requirements and found no excuses for excuses or justifications, so that criminal liability can be requested from the Director of a Limited Liability Company. Based on the above, the judge sentenced him to 5 (five) years in prison as a form of criminal liability to the Director of PT. Care Indonusa.

Keywords: Criminal Libiality, Director of Limited Liabiity Company, Corruption Crime
\end{abstract}

\begin{abstract}
Abstrak
Keberadaan korporasi dalam ketentuan KUHP yang berlaku pada saat ini belum mengatur dengan jelas korporasi sebagai pelaku tindak pidana sebab hanya Pasal 59 KUHP yang masih mengatur ketentuan korporasi. Akan tetapi, dalam ketentuan peraturan diluar KUHP telah mengatur dengan jelas keberadaan korporasi sebagai subyek hukum seperti halnya UndangUndang Nomor 40 Tahun 2007 tentang Perseroan Terbatas. Kejahatan criminal corporate dalam perkembangannya telah meluas dalam kehidupan masyarakat, hal ini dapat dilakukan

Pertanggungjawaban Pidana Direktur Perseroan Terbatas Dalam Tindak Pidana Korupsi Proyek Terbatas Dalam Tindak Pidana Korupsi Proyek Pembangunan Rumah Sakit (Studi Putusan No. 15/Pid.SusTPK/2018/PN.Mdn)
\end{abstract}


oleh pengurus dari korporasi itu sendiri. Bentuk korporasi dalam perkembangannya ada yang berbentuk berbadan hukum dan yang tidak berbadan hukum, salah satu yang berbadan hukum adalah Perseroan Terbatas, di dalam Pasal 82 UUPT Direktur adalah pengurus dari perseroan, maka Direktur mewakili Perseroan Terbatas kedalam dan keluar sesuai dengan Pasal 82 UUPT. Adapun yang menjadi permasalahan dalam penelitian ini adalah bagaimana pertanggungjawaban pidana Direktur Perseroan Terbatas dalam tindak pidana korupsi proyek pembangunan rumah sakit (studi putusan nomor 15/Pid.Sus-TPK/2018/PN.Mdn)

Metode penelitian hukum yang digunakan dalam penelitian ini adalah jenis penelitian hukum normatif yaitu penelitian yang digunakan dengan cara menelusuri atau menelaah dan menganalisis bahan pustaka, salah satunya ada Putusan No. 15/Pid.Sus-TPK/2018/PN.Mdn. Maka berdasarkan hasil penelitian terhadap Putusan No. 15/Pid.Sus-TPK/2018/PN.Mdn dapat disimpulkan bahwa berdasarkan perbuatan dan kesalahan Direktur PT. Care Indonusa telah memenuhi unsur kesalahan, syarat pertangungjawaban pidana dan tidak ditemukannya alasan pemaaf maupun alasan pembenar, sehingga pertanggungjawaban pidana dapat dimintakan kepada Direktur Perseroan Terbatas. Atas dasar hal tersebut diatas Hakim menjatuhkan hukuman selama 5 (lima) tahun penjara sebagai bentuk pertanggungjawaban pidana kepada Direktur PT. Care Indonusa.

Kata kunci: Pertanggungjawaba Pidana, Direktur Perseroan Terbatas, Tindak Pidana Korupsi

\section{A. Pendahuluan}

Dalam Undang-Undang Dasar NRI 1945 ditegaskan bahwa negara Indonesia berdasarkan atas hukum (rechtstaat), tidak berdasarkan atas kekuasaan belaka (machstaat). Ini berarti bahwa Republik Indonesia adalah negara hukum yang demokratis berdasarkan pancasila dan Undang-Undang Dasar NRI 1945, menjunjung tinggi hak asasi manusia, dan menjamin semua warga negara bersamaan kedudukannya di dalam hukum dan pemerintahan serta wajib menjunjung hukum dan pemerintahan itu dengan tidak ada kecualinya. ${ }^{1}$

Hukum menetapkan apa yang harus dilakukan dan atau yang boleh dilakukan serta yang dilarang. Sasaran hukum yang hendak dituju bukan saja orang yang nyata-nyata berbuat melawan hukum, melainkan juga perbuatan hukum yang mungkin akan terjadi, dan kepada alat perlengkapan negara untuk bertindak menurut hukum. Sistem bekerjanya hukum yang demikian itu merupakan salah satu bentuk penegakan hukum.

Demikian juga halnya dengan perbuatan korupsi, hukum juga telah mengatur sebagai perbuatan yang tidak boleh dilakukan serta yang dilarang. Angka korupsi di Indonesia terus menunjukkan peningkatan dari tahun ke tahun, berdasarkan data kasus dari ICW pada tahun 2017 angka korupsi mengalami peningkatan pada sektor Apartur Sipil Negara (ASN) sebesar 495 kasus dan pada sektor swasta sebesar 241 kasus. ${ }^{2}$ Tindak pidana korupsi telah meluas dalam kehidupan pemerintahan maupun swasta, hal ini dapat dilihat dari beberapa kasus korupsi yang terjadi pada sektor swasta misalnya seperti korupsi anggaran proyek dan korupsi pengadaan barang dan jasa. Pada kenyataannya tindak pidana korupsi tidak hanya dapat dilakukan manusia perorangan saja yang bisa menjadi subyek hukum. Perseroan juga bisa menjadi subyek hukum. Oleh karena itu, Apabila sesuatu mempunyai hak dan kewajiban seperti layaknya manusia, maka menurut hukum setiap apa pun yang mempunyai hak dan kewajiban adalah subyek hukum dalam kategori badan hukum. Dengan demikian, tidak selamanya badan hukum harus manusia (natural person). Tetapi badan hukum yang bukan manusia itulah yang disebut Perseroan Terbatas (naamlozevetnootschap).

\footnotetext{
${ }^{1}$ Evi Hartanti, Tindak Pidana Korupsi, Jakarta, Sinar Grafika, 2012, hlm. 1.

${ }^{2}$ Lihat https://antikorupsi.org/sites/default/files/tren_korupsi_2017.pdf., diakses pada tgl 25 Maret 2019, pukul 20.10 wib.

Pertanggungjawaban Pidana Direktur Perseroan Terbatas Dalam Tindak Pidana Korupsi Proyek Terbatas Dalam Tindak Pidana Korupsi Proyek Pembangunan Rumah Sakit (Studi Putusan No. 15/Pid.SusTPK/2018/PN.Mdn) 
Dalam ketentuan KUHP yang berlaku pada saat ini belum mengatur dengan jelas korporasi sebagai pelaku tindak pidana sebab hanya Pasal 59 KUHP yang masih mengatur ketentuan korporasi yakni "dalam hal-hal ini dimana karena pelanggaran ditentukan pidana terhadap pengurus, anggota-anggota badan pengurus atau komisaris-komisaris, maka pengurus, anggota badan pengurus atau komisaris yang ternyata tidak ikut campur melakukan pelanggaran tindak pidana". Akan tetapi, beberapa ketentuan diluar KUHP telah mengatur korporasi sebagai pelaku tindak pidana korupsi hal ini dapat diketahui dalam Undang-Undang Tindak Pidana Korupsi yang telah mengatur keberadaan korporasi sebagai subyek hukum tindak pidana korupsi. Korporasi sebagai pelaku tindak pidana adalah berkaitan dengan pertanggungjawaban pidana, yang dimaksud pertanggungjawaban pidana adalah mampu untuk mengerti nilai dari akibat-akibat perbuatannya sendiri, mampu untuk menyadari bahwa perbuatannya itu menurut pandangan masyarakat tidak dibolehkan, dan mampu untuk menentukan kehendaknya atas perbuatan-perbuatannya itu. Ketentuan Pasal 20 UndangUndang Nomor 20 Tahun 2001 tentang Tindak Pidana Korupsi menyebutkan:

1. Dalam hal tindak pidana korupsi oleh atau atas nama suatu korporasi, maka tuntutan dan penjatuhan pidana dapat dilakukan terhadap korporasi dan/atau pengurusnya.

2. Tindak pidana korupsi dilakukan korporasi apabila tindak pidana tersebut dilakukan oleh orang-orang baik berdasarkan hubungan kerja maupun berdasarkan hubungan lain, bertindak dalam lingkungan korporasi tersebut baik sendiri maupun bersamasama.

3. Dalam hal tuntutan pidana dilakukan terhadap suatu korporasi maka korporasi tersebut diwakili oleh pengurus.

4. Pengurus yang mewakili korporasi sebagaimana dimaksud dalam ayat (3) dapat diwakili oleh orang lain.

5. Hakim dapat memerintahkan supaya pengurus korporasi menghadap sendiri di pengadilan dan dapat pula memerintahkan supaya pengurus tersebut dibawa ke sidang pengadilan.

6. Dalam hal tuntutan pidana dilakukan terhadap korporasi, maka panggilan untuk menghadap dan penyerahan surat panggilan tersebut disampaikan kepada pengurus di tempat tinggal pengurus atau di tempat pengurus berkantor.

7. Pidana pokok yang dapat dijatuhkan terhadap korporasi hanya pidana denda, ketentuan maksimum pidana ditambah $1 / 3$ (satu per tiga).

Pada Pasal 20 Undang-Undang Tindak Pidana Korupsi menjelaskan bahwa yang menjadi subyek hukum adalah manusia dan korporasi. Yang dimaksud korporasi berdasarkan Pasal 1 angka (1) Undang-Undang Nomor 40 Tahun 2007 yaitu "perseroan yang selanjutnya disebut perseroan, adalah badan hukum yang merupakan persekutuan modal, didirikan berdasarkan perjanjian, melakukan kegiatan usaha dengan modal dasar yang seluruhnya terbagi dalam saham dan memenuhi persayaratan yang ditetapkan dalam undang-undang ini serta peraturan pelaksanaannya".

Bentuk korporasi pada perkembangannya ada yang berbentuk berbadan hukum dan yang tidak berbadan hukum, yang berbadan hukum adalah Perseroan Terbatas (PT), Yayasan, Koperasi, sedangkan yang tidak berbadan hukum adalah Commanditaire Vennootschap (CV), Firma, dan Persekutuan Perdata. Perseroan Terbatas sebagai badan hukum diakui oleh Undang-Undang Nomor 40 Tahun 2007, dan tidak lepas kaitannya dengan Pasal 20 UndangUndang Nomor 20 Tahun 2001. Jika Perseroan Terbatas melakukan tindak pidana korupsi, maka yang bertanggung jawab mewakili Perseroan adalah pengurus yang pada dasarnya dapat 
mewakili perusahaan, di dalam Undang-Undang Nomor 40 Tahun 2007 yang dimaksud dengan pengurus adalah Direksi bersama dengan Komisaris.

Pengertian Direksi berdasarkan Pasal 1 angka (5) Undang-Undang Nomor 40 Tahun 2007 adalah "organ perseroan yang berwenang dan bertanggung jawab penuh atas pengurusan perseroan untuk kepentingan perseroan, sesuai dengan maksud dan tujuan perseroan serta mewakili perseroan, baik di dalam maupun di luar pengadilan sesuai dengan ketentuan anggaran dasar" dan pengertian Dewan Komisaris berdasarkan Pasal 1 angka (6) Undang Nomor 40 Tahun 2007 adalah "organ perseorangan yang bertugas melakukan pengawasan secara umum dan/atau khusus sesuai dengan anggaran dasar serta memberi nasihat kepada Direksi".

Kejahatan tindak pidana korupsi dewasa ini banyak dilakukan oleh direksi dari perseroan terbatas, bila melihat kedudukan direksi sebagai wakil perseroan yang persona in judicio atau subjek hukum mandiri. Pengangkatan direksi oleh RUPS harus dipandang sebagai mandat kepada direksi untuk oversee management and return profits bagi pemegang saham. Karena antara lain hal inilah, maka direksi dianggap sebagai organ perseroan yang penting (primary organ). Tugas dan kewajiban serta wewenang direksi suatu perseroan menurut Undang-Undang Nomor 40 Tahun 2007 tentang Perseroan Terbatas dalam Pasal 92 ayat (1) yang menyatakan "direksi menjalankan pengurusan perseroan untuk kepentingan perseroan dan sesuai dengan maksud dan tujuan perseroan”. Apabila tugas dan kewajiban itu dilakukan atau wewenang jabatan itu telah disalahgunakan, akan membawa konsekuensi terhadap pejabat/pengurus yang melalaikannya itu. Pejabat/pengurus tersebut harus bertanggung jawab atas kelalaiannya itu atau penyalahgunaan kewenangannya itu. Demikian pula untuk jabatan anggota Direksi suatu perseroan.

Pertanggungjawaban direksi pada pokoknya bersifat kolegial dan di antara anggotanya boleh diadakan pembagian tugas. Pembagian tugas ini merupakan tata kelola internal organisasi perseroan yang mengikat ke dalam, dan tidak mengikat pihak ketiga, sehingga dalam berhubungan dengan perseroan pihak ketiga tidak perlu meneliti ruang lingkup kewenangan anggota direksi yang bersangkutan sesuai anggaran dasar perseroan tersebut. Namun demikian, setiap anggota direksi bertanggung jawab secara pribadi bila bersalah atau lalai saat menjalankan tugasnya, sekaligus membuka kemungkinan tanggug jawab renteng di antara anggota direksi. ${ }^{3}$

Dengan dimungkinkannya anggota direksi lebih dari satu orang, maka di antara mereka harus melakukan check and balance, agar kesalahan atau kelalaian di antara mereka yang bisa menimbulkan tanggung jawab pribadi dapat diminimalisasi. Jika ada pembagian tugas, maka anggota direksi yang ditugasi mengurus bidang tertentu tidak wajib secara terikat secara terusmenerus menekuni bidang tugas anggota direksi yang lain. Untuk ini ada yang berpendapat bahwa seorang anggota direksi tidak bertanggung jawab atas kelalaian yang dilakukan anggota direksi lain, yang terjadi di luar bidangnya.

Pandangan Hasbullah F. Sjawie mengatakan bahwa sistem pertanggungjawaban direksi adalah tanggung renteng, dan bilamana terdapat lebih dari satu orang anggota direksi disuatu perseroan, maka sebagaimana yang ditegaskan melalui Pasal 97 ayat (4) Undang-Undang Nomor 40 Tahun 2007 tentang Perseroan Terbatas, pendapat diatas tidak seluruhnya dapat diterima. Memang ayat (5) dari Pasal 97 memberi kemungkinan bahwa seorang anggota direksi bisa terlepas dari tanggung jawab renteng, akan tetapi untuk bisa sampai kepada titik itu terdapat empat persyaratan, dan salah satunya adalah bahwa anggota direksi yang bersangkutan telah melakukan pengurusan dengan itikad baik dan kehati-hatian untuk

\footnotetext{
${ }^{3}$ Hasbullah F. Sjawie, Direksi Perseroan Terbatas serta Pertanggungjawaban Pidana Korporasi, Jakarta, Kencana, 2017, hlm. 154.

Pertanggungjawaban Pidana Direktur Perseroan Terbatas Dalam Tindak Pidana Korupsi Proyek Terbatas Dalam Tindak Pidana Korupsi Proyek Pembangunan Rumah Sakit (Studi Putusan No. 15/Pid.Sus- 
kepentingan dan sesuai dengan maksud dan tujuan perseroan. Ketentuan ini pada dasarnya menutup kemungkinan bagi para anggota direksi untuk bisa bersikap tidak peduli satu sama lain, bila ada pembagian tugas diantara mereka. Pembagian tugas tidak bisa dijadikan alat untuk membela diri dengan mengatakan bahwa karena bidang tertentu itu bukan tugasnya, maka tidak ada kewajiban hukum pada dirinya untuk peduli pada bidang yang bukan tugasnya. ${ }^{4}$

Dampak dan akibat dari tindak pidana korupsi dinyatakan dalam Undang-Undang Nomor 20 Tahun 2001 tentang perubahan atas Undang-Undang Nomor 31 Tahun 1999 tentang Pemberantasan Tindak Pidana Korupsi. Bagian penjelasan undang-undang tersebut menyatakan bahwa: “...mengingat korupsi di Indonesia terjadi secara sistematik dan meluas sehingga tidak hanya merugikan keuangan negara, tetapi juga telah melanggar hak-hak sosial dan ekonomi masyarakat secara luas, maka pemberantasan korupsi perlu dilakukan dengan cara luar biasa..."

\section{B. Metode Penelitian}

Metode Pendekatan Masalah

Pendekatan masalah yang digunakan adalah pendekatan yuridis normatif yaitu pendekatan yang dilakukan penelaan terhadap norma-norma baik yang terdapat di dalam peraturan perundang-undangan dan dokumen-dokumen pengadilan.

Teknik Pengumpulan Data

Dalam penulisan penelitian ini, penulis menggunakan metode penulisan yaitu metode penelitian hukum normatif. Metode penulisan hukum normatif terdiri dari:

1. Bahan hukum primer (primary law material)

Bahan hukum primer merupakan bahan hukum yang bersifat autoritatif artinya mempunyai otoritas. Bahan hukum primer terdiri dari peraturan perundangundangan, risalah dalam pembuatan peraturan perundang-undangan, dan putusan hakim. ${ }^{6}$ Adapun yang termasuk sebagai sumber bahan hukum primer yang akan dipergunakan dalam mengkaji setiap permasalahan dalam penulisan penelitian ini, yaitu :

a. Perundang-undangan

b. Undang-Undang Nomor 1 Tahun 1946 tentang Peraturan Hukum Pidana

c. Undang-Undang Nomor 8 Tahun 1981 tentang Hukum Acara Pidana

d. Undang-Undang Nomor 20 Tahun 2001 tentang Pemberantasan Tindak Pidana Korupsi

e. Undang-Undang Nomor 40 Tahun 2007 tentang Perseroan Terbatas

f. Putusan Pengadilan Nomor 15/Pid. Sus-TPK/2018/PN.Mdn.

2. Bahan hukum sekunder

Bahan hukum sekunder merupakan bahan hukum yang berupa semua publikasi tentang hukum yang bukan merupakan dokumen-dokumen resmi. Publikasi tentang hukum meliputi buku-buku literatur, jurnal-jurnal hukum, pendapat para ahli, tulisan-tulisan hukum, sumber dari internet yang relevan dengan permasalahan yang dibahas.

3. Bahan hukum tersier

\footnotetext{
${ }^{4}$ Ibid., hlm. 155 .

${ }^{5}$ Kristian dan Yopi Gunawan, Tindak Pidana Korupsi Kajian terhadap Harmonisasi antara Hukum Nasional dan The United Nations Convention Against Corruption (UNCAC), Bandung, Refika Aditama, 2015, hlm. 104.

${ }^{6}$ Peter Mahmud Marzuki, Metode Penelitian Hukum, Jakarta, Kencana Prenanda Media Group, 2014, hlm. 181. Pertanggungjawaban Pidana Direktur Perseroan Terbatas Dalam Tindak Pidana Korupsi Proyek Terbatas Dalam Tindak Pidana Korupsi Proyek Pembangunan Rumah Sakit (Studi Putusan No. 15/Pid.Sus- 
Bahan hukum tersier adalah bahan hukum yang memberi petunjuk maupun penjelasan terhadap bahan hukum primer dan sekunder, yakni kamus hukum serta hal-hal yang bisa memberikan petunjuk yang erat hubungannya dengan masalah yang diteliti.

\section{Pembahasan}

Pertanggungjawaban Pidana Direktur Perseroan Terbatas Dalam Tindak Pidana Korupsi Proyek Pembangunan Rumah Sakit (Studi Putusan Nomor 15/Pid.SusTPK/2018/PN.Mdn)

\section{A. Kasus Polisi}

Pengadilan Tindak Pidana Korupsi pada Pengadilan Negeri Medan yang mengadili perkara tindak pidana korupsi dengan acara pemeriksaan biasa pada peradilan tingkat pertama menjatuhkan putusan sebagai berikut terhadap terdakwa:

$\begin{array}{lll}\text { Nama lengkap } & : & \text { DEDI HERMAWAN. } \\ \text { Tempat lahir } & : & \text { Tanjung Gading. } \\ \text { Umur/Tanggal lahir } & : & \text { 30 Tahun/19 Mei } 1986 . \\ \text { Jenis Kelamin } & : & \text { Laki-laki. } \\ \text { Kebangsaan } & : & \text { Indonesia. } \\ \text { Tempat lahir } & : & \text { Dusun III Desa Tanjung Gading } \\ & & \text { Kecamatan Sei Suka. } \\ \text { Agama } & : & \text { Islam. } \\ \text { Pekerjaan } & : & \text { Direktur PT. Care Indonusa. } \\ \text { Pendidikan } & : & \text { SMA. }\end{array}$

Bahwa berdarkan laporan Kemajuan Pelaksanaan Pekerjaan dan Berita Acara Pemeriksaan Prestasi Pekerjaan No. 050/8863/PPSPRS-PU/APBD/2015 Tanggal 18 Desember 2015 yang ditandatangani oleh Direktur PT. CARE INDONUSA yaitu terdakwa DEDI HERMAWAN, serta diperiksa oleh pejabat Pelaksana Teknis Kegiatan (PPTK) yaitu saksi KHAIRUDDIN, S.T., dan Pengawas Lapangan saksi ANDRY ANTA KESUMA, S.T., dan saksi PADLAN, S.T., serta disetujui oleh Pejabat Pembuat Komitmen (PPK) yaitu saksi ZULKARNAIN AMRULLAH bahwa progress pekerjaan fisik di lapangan telah dilaksanakan 70\%, padahal waktu saksi Andry, S.T., dan Fadlan, S.H., melakukan pengecekan ke lapangan menemukan cerocok kayu pondasi, pagar seng masih kurang, timbunan masih kurang.

Bahwa perbuatan Terdakwa DEDI HERMAWAN selaku Direktur PT. CARE INDONUSA yang menerima pembayaran $60 \%$ padahal diketahuinya volume pekerjaan terpasang tidak sesuai dengan kondisi senyatanya, yang belum mencapai 70\%, maka Terdakwa DEDI HERMAWAN menguntungkan diri sendiri setidak-tidaknya korporasi atau Perusahaan PT. CARE INDONUSA serta setidak-tidaknya orang lain yaitu ZULKARNAIN AMIRULLAH sehingga perbuatan terdakwa telah merugikan keungan negara sebesar Rp. 1.013.877.289,19,(satu miliar tiga belas juta delapan ratus tujuh puluh tujuh ribu dua ratus delapan puluh sembilan koma sembilan belas rupiah) atau setidak-tidaknya sekitar jumlah tersebut sesuai laporan hasil audit dalam rangka penghitungan kerugian negara atas dugaan tindak pidana korupsi pada lanjutan pembangunan Rumah Sakit Type $C$ kota Tanjung Balai Nomor: Anggaran 2015 sesuai dengan LHP 34/LHP/XXI/11/2017 tanggal 13 November 2017 dari BPK Republik Indonesia. 


\section{B. Dakwaan Jaksa Penuntut Umum}

Berdasarkan kasus posisi yang dikemukakan diatas, maka Jaksa Penuntut Umum (JPU) pada Pengadilan Negeri Medan mengajukan Terdakwa ke Persidangan dengan dakwaan Primair dan Subsidair yaitu:

Primair : Pasal 2 ayat (1) jo. Pasal 18 ayat (1) Undang-Undang Nomor 31 Tahun 1999 tentang Pemberantasan Tindak Pidana Korupsi sebagaimana diubah dengan Undang-Undang Nomor 20 Tahun 2001 tentang perubahan atas Undang-Undang Nomor 31 Tahun 1999 jo. Pasal 55 ayat (1) ke-1 KUHP.

Subsidiair : Pasal 3 jo. Pasal 18 ayat (1) Undang-Undang Nomor 31 Tahun 1999 tentang Pemberantasan Tindak Pidana Korupsi sebagaimana diubah dengan Undang-Undang Nomor 20 Tahun 2001 tentang perubahan atas Undang-Undang Nomor 31 Tahun 1999 jo. Pasal 55 ayat (1) ke-1 KUHP.

\section{Tuntutan Jaksa Penuntut Umum}

Tuntutan dari Jaksa Penuntut Umum (JPU) yang diajukan kepada majelis Hakim yang pada pokoknya Jaksa Penuntut Umum menyatakan:

1. Menyatakan Terdakwa terbukti secara sah dan meyakinkan bersalah melakukan Tindak Pidana Korupsi sebagaimana diatur dan diancam pidana dalam Pasal 2 ayat (1) jo. Pasal 18 ayat (1) b Undang-Undang Nomor 31 Tahun 1999 tentang Pemberantasan Tindak Pidana Korupsi sebagaimana diubah dengan Undang-Undang Nomor 20 Tahun 2001 tentang perubahan atas Undang-Undang Nomor 31 Tahun 1999 tentang Pemberantasan Tindak Pidana Korupsi jo. Pasal 55 ayat (1) ke-1 KUHPidana.

2. Menjatuhkan pidana penjara kepada Terdakwa DEDI HERMAWAN selama 6 (enam) tahun dengan perintah Terdakwa tetap ditahan di Rutan dan membayar denda sebesar Rp. 200.000.000,- (dua ratus juta rupiah) subsidair 4 (empat) bulan kurungan.

3. Bahwa terhadap Terdakwa dibebankan untuk membayar uang pengganti sebesar Rp. 1.337.442.298,- (satu miliar tiga ratus tiga puluh tiga tujuh juta empat ratus empat puluh dua ribu dua ratus sembilan puluh delapan rupiah) jika Terdakwa tidak sanggup membayar uang pengganti paling lama dalam waktu 1 (satu) bulan sesudah putusan pengadilan yang berkekuatan hukum tetap, maka harta bendanya dapat disita oleh Jaksa dan dilelang untuk menutupi uang pengganti tersebut, dalam hal Terdakwa tidak mempunyai harta benda yang mencukupi untuk membayar uang pengganti, maka akan diganti dengan pidana penjara selama 1 (satu) tahun penjara.

4. Menyatakan barang bukti berupa:

- Dokumen Pelaksanaan Anggaran (DPA) T.A. 2015;

- $\quad$ Dokumen Perubahan Pelaksanaan Anggaran (DPPA) T.A. 2015;

- $\quad$ Rencana Kerja Anggaran (RKA) T.A. 2015 Dinas PU; 
- SK Penetapan PPK terkait lampiran SK Pengguna Anggaran Nomor 050/27a/K/2015 tanggal 24 Februari 2015;

- $\quad$ SK Penetapan PPTK lampiran SK Pengguna Anggaran Nomor 050/27a/K/2015 tanggal 24 Februari 2015;

- $\quad$ SK Penetapan Pokja pada Dinas PU, tanggal 30 Maret 2015;

- $\quad$ SK Penetapan PPHP, SK Kepala Dinas PU Nomor 050/980/PU/2015, tanggal 29 Juli 2015 tentang Penetapan Panitia Pemeriksa/Penerima Hasil Pekerjaan pada Dinas PU;

- Surat Perintah penunjukan Sdr. Mulkan, S.T., sebagai Plt. Kadis PU dan Penataan Ruang Kota Tanjung Balai, tanggal 3 Juni 2017;

- $\quad$ SK Walikota tentang Mutasi terkait Sdr. Drg. Azhari Sima, tanggal 28 April 2011;

- $\quad$ Dokumen HPS;

- Dokumen Rencana Anggaran Biaya;

- $\quad$ Surat Perjanjian Pekerjaan Nomor 050/oo6/SPP/PD/I-PU/APBD/2015 tanggal 5 Juni 2015 terkait kontrak pekerjaan konsultansi perencanaan.

5. Menetapkan agar Terdakwa dibebani membayar biaya perkara sebesar Rp. 5.ooo,(lima ribu rupiah).

\section{Dasar Pertimbangan Hakim}

Menimbang bahwa untuk membuktikan dakwaannya, Penuntut Umum telah mengajukan keterangan ahli dan keterangan saksi yang masing-masing di Persidangan telah didengar keterangan pada pokoknya sebagai berikut:

a) Keterangan Ahli

1. Yuli Rachman, S.T., CfrA.

- Bahwa ahli adalah ahli di bidang penghitungan kerugian negara yang mewakili Badan Pemeriksaan Keuangan Republik Indonesia (BPK-RI);

- Bahwa berdasarkan laporan hasil pemeriksaan investigatif dalam rangka penghitungan kerugian negara atas pengadaan pekerjaan paket lanjutan pembangunan rumah sakit type C kota Tanjung Balai T.A. 2015 mencakup penyimpangan dalam pemilihan penyedia jasa dan penyimpangan dalam pelaksanaan kontrak, dengan penjelasan sebagai berikut:

a. Penyimpangan dalam pemilihan penyedia jasa hasil pemeriksaan dalam penyedia jasa menunjukkan bahwa adanya dugaan persaingan tidak sehat dalam proses lelang, surat keterangan dukungan bank untuk PT. Care Indonusa tidak diakui Bank Sumut, dan Sertifikat Keterampilan Kerja (SKK) personel PT. Care Indonusa tidak terdapat pada situs LPJK.

b. Penyimpangan dalam pelaksanaan kontrak hasil pemeriksaan atas dalam pelaksanaan kontrak, yaitu:

1) Penyusunan Change Contract Order ( $\mathrm{CCO}$ ) tidak didukung dengan hasil pengukuran/perhitungan teknik dan usulan dari penyedia jasa. 
2) Berita acara pembayaran dan berita acara pemeriksaan prestasi pekerjaan untuk pembayaran termin 6o\% tanggal 18 Desember 2015 dibuat tidak sesuai dengan kondisi senyatanya; dan

3) Volume pekerjaan terpasang tidak sesuai kontrak.

- Bahwa sehingga penyimpangan-penyimpangan yang disebabkan oleh pihak-pihak terkait tersebut mengakibatkan terjadinya kerugian negara sebesar Rp. 1.013.877.289,- (satu miliar tiga belas juta delapan ratus tujuh ribu dua ratus delapan puluh sembilan koma sembilan belas rupiah);

- Bahwa metode penghitungan yang digunakan ahli adalah berdasarkan laporan hasil pemeriksaan investigatif dalam rangka penghitungan kerugian negara atas pengadaan pekerjaan paket lanjutan pembangunan rumah sakit type $C$ kota Tanjung Balai T.A. 2015 sesuai dengan LHP 34/LHP/XXI/11/2017 tanggal 13 November 2017, BPK menyatakan bahwa perhitungan kerugian negara sebesar Rp. 1.013.877.289.19,-- diperoleh dari pembayaran bersih berasal dari pembayaran dikurangi PPN dan dikurangi nilai pekerjaan terpasang.

b) Keterangan Saksi

1. Muhammad Amin, S.T., M.T., yang pada pokoknya menerangkan sebagai berikut:

- Bahwa saksi dalam kegiatan lanjutan pembangunan rumah sakit type C kota Tanjung Balai T.A. 2015 tersebut adalah sebagai ketua POKJA berdasarkan keputusan kepala unit layanan pengadaan barang/jasa pemerintah kota Tanjung Balai Nomor: 0o6/K/ULP/2015 tanggal 30 Maret 2015;

- Bahwa benar tugas pokok dan fungsi saksi selaku ketua POKJA pengadaan barang dan jasa adalah:

a) Menyusun rencana pemilihan penyedia barang/jasa.

b) Mengusulkan kepada PPK perubahan HPS dan/atau perubahan spesifikasi tekhnis pekerjaan.

c) Menetapkan dokumen pengadaan.

d) Menetapkan besaran nominal jaminan penawaran.

e) Menilai kualifikasi penyedia barang/jasa melalui prakualifikasi atau pasca kualifikasi.

f) Melakukan evaluasi administrasi, tekhnis dan harga terhadap penawaran yang masuk.

g) Melakukan klarifikasi terhadap penawaran penyedia barang/jasa dan melakukan uji tekhnis bila diperlukan.

h) Menetapkan penyedia barang/jasa untuk:

1. Pengadaan barang/pekerjaan konstruksi/jasa lainnya dengan nilai diatas Rp. 200.000.00o,- (dua ratus juta rupiah);

2. Pengadaan jasa konsultasi dengan nilai diatas Rp. 50.000.00o,- (lima puluh juta rupiah). 
i) Menjawab sanggahan.

j) Menyampaikan hasil pemilihan dan salinan dokumen pemilihan penyedia barang/jasa kepada Pejabat Pembuat Komitmen (PPK).

k) Menandatangani pakta integritas sebelum pelaksanaan pengadaan barang/jasa dimulai, dan

1) Membuat laporan mengenai proses dan hasil pengadaan kepada kepala ULP.

- Bahwa lelang terhadap pekerjaan/kegiatan dimaksud dilaksanakan tanggal 14 Agustus 2015 s/d 17 Agustus 2015 yang dilakukan dengan cara metode pemilihan langsung dengan pasca kualifikasi;

- Bahwa sumber anggarannya berasal APBD kota Tanjung Balai tahun anggaran 2015 dengan pagu anggaran sebesar Rp. 3.580.300.ooo,- (tiga miliar lima ratus delapan puluh juta tiga ratus ribu rupiah) dengan nama paket pekerjaan yakni lanjutan pembangunan rumah sakit type $C$ kota Tanjung Balai T.A. 2015;

- Bahwa pelaksanaan lelang dilakukan dengan menggunakan system elektronik selama 4 (empat) hari dan dilaksanakan penjelasan dokumen lelang 3 (tiga) hari setelah pengumuman lelang, kemudian peserta lelang dapat mengupload masing-masing dokumen penawaran setelah pelaksanaan penjelasan dokumen lelang dilaksanakan kemudian dilakukan pembukaan penawaran 3 (tiga) hari setelah pemberian penjelasan, kemudian proses lelang itu sendiri dilaksanakan sebanyak 1 (satu) kali dan perusahaan yang mendaftar sebanyak 20 (dua puluh) perusahaan. Namun, yang memasukkan dokumen penawaran hanya 3 (tiga) perusahaan dan itu telah sesuai dan dasar pelaksanaan lelang adalah Perpres 04 Tahun 2015;

- Bahwa pada proses lelang yang memasukkan dokumen penawaran ada 3 (tiga) perusahaan yakni CV. AZRI GROUP dan CV. YADON BARA tidak lulus evaluasi administrasi dikarenakan penawaran CV. YADON BARA juga diupload oleh CV. AZRI GROUP. Hal ini menunjukkan bahwa kedua perusahaan secara langsung maupun tidak langsung berada di bawah kepemilikan yang sama, sehingga CV. YADON BARA tidak memenuhi persyaratan administrasi dan mengakibatkan CV. AZRI GROUP, dan CV. YADON BARA digugurkan, hal ini dapat dilihat dan dituangkan dalam SUMMARY REPORT/lelang elektronik yang terdapat dalam LPSE kota Tanjung Balai lalu kepada dinas PU kota Tanjung Balai selaku PPK menerbitkan SPPBJ (Surat Penunjukan Penyedia Barang dan Jasa);

- Bahwa dalam proses evaluasi administrasi yang lolos hanya 1 (satu) perusahaan saja kemudian perusahaan tersebut yakni PT. CARE INDONUSA mengikuti evaluasi tekhnis dan evaluasi biaya/harga dan perusahaan tersebut masih lolos sehingga PT. CARE INDONUSA ditetapkan dan diumumkan sebagai pemenang lelang dalam kegiatan dimaksud; 
- Bahwa pemenang lelang dalam kegiatan lanjutan pembangunan rumah sakit type C kota Tanjung Balai adalah PT. CARE INDONUSA dengan Direktur adalah DEDY HERMAWAN;

- Bahwa setelah ditetapkan sebagai pemenang maka POKJA mengumumkan pemenang lelang dan membuat berita acara lelang setelah itu melaporkan kepada ULP yang mana pelaporan tersebut setelah masa sanggah selesai dimana masa sanggah dalam kegiatan ini sejak tanggal 27 Agustus 2015 s/d tanggal 29 Agustus 2015;

- Bahwa perubahan HPS dapat dilakukan sebelum pengumuman lelang, dimana PPK mengusulkan dokumen paket yang akan dilelangkan kepada ULP dan sampai pada saat ULP menyerahkan kepada POKJA untuk dilelangkan tidak ada perubahan HPS sehingga tahapan lelang tetap dapat dilaksanakan;

- Bahwa saksi tidak ada menerima uang baik dari rekanan maupun dari siapapun terkait tugas saksi selaku ULP;

2. Denny Chandra, yang pada pokoknya menerangkan sebagai berikut:

- Bahwa dalam kegiatan lanjutan pembangunan rumah sakit type C kota Tanjung Balai T.A. 2015 tersebut yang bersangkutan adalah sebagai Bendahara pengeluaran dinas PU kota Tanjung Balai T.A. 2015 dengan dasar diangkatnya menjadi bendahara pengeluaran di dinas PU kota Tanjung Balai berdasarkan keputusan Walikota Tanjung Balai nomor: 900/110/K/2015 tentang perubahan keempat atas keputusan Walikota Tanjung Balai nomor: 900/o8/K/2015 tanggal o5 Januari 2015 tentang penunjukan dan penetapan bendahara penerimaan, bendahara pengeluaran, bendahara penerimaan pembantu, dan bendahara pengeluaran pembantu pada Satuan Kerja Perangkat Daerah (SKPD) di lingkungan pemerintah kota Tanjung Balai T.A. 2015;

- Bahwa tugas pokok dan fungsi yang bersangkutan selaku Bendahara pengeluaran dinas PU kota Tanjung Balai adalah:

a. Mengajukan dokumen SPP-UP, SPP-GU, SPP-TU, SPP-LS kepada pengguna anggaran/kuasa pengguna anggaran melalui PPK-SKPD.

b. Menyelenggarakan penata usahaan terhadap seluruh pengeluaran yang menjadi tanggungjawabnya berdsarkan bukti pengeluaran yang sah.

c. Bendahara pengeluaran pada SKPD wajib mempertanggungjawabkan secara administratif atas pengelolaan uang yang menjadi tanggungjawabnya dengan menyampaikan laporan pertanggungjawaban pengeluaran kepada pengguna anggaran/kuasa pengguna anggaran melalui PPK-SKPD dan mempertanggungjawabkan secara fungsional kepada kepala dinas pendapatan pengelolaan keuangan dan aset kota Tanjung Balai selaku pejabat pengelola keuangan daerah paling lambat tanggal 10 bulan berikutnya. 
d. Bendahara pengeluaran dalam melaksanakan tugas dan tanggungjawabnya dapat dibantu oleh bendahara pengeluaran pembantu.

e. Melakukan pemeriksaan kas yang dikelola oleh bendahara pengeluaran pembantu sekurang-kurangnya 1 (satu) kali dalam 3 (tiga) bulan.

f. Melakukan verifikasi, evaluasi dan analisis terhadap laporan pertanggungjawaban penerimaan pengeluaran bendahara pembantu.

- Bahwa yang bersangkuatan tidak pernah mengikuti diklat keuangan baik di provinsi maupun di kota madya;

- Bahwa yang menjadi rekanan dalam kegiatan ini adalah PT. CARE INDONUSA dengan Direkturnya adalah DEDI HERMAWAN dan nilai kontrak sebesar Rp. 3·550.00o.ooo,- (tiga miliar lima ratus lima puluh juta rupiah) yang sumber dananya berasal dari APBD Tahun 2015;

- Bahwa yang bersangkutan sebagai bendahara pengeluaran bertanggungjawab kepada PPK yakni kepala dinas PU kota Tanjung Balai ZULKARNAIN AMRULLAH, S.T.;

- Bahwa pencairan dalam kegiatan ini dilaksanakan sebanyak 2 (dua) kali yaitu:

a. Pembayaran pertama termin uang muka sebesar $20 \%$ dari nilai kontrak yaitu Rp. 710.000.00o,- (tujuh ratus sepuluh juta rupiah) dan yang diterima rekanan setelah dipotong pajak penghasilan Ps 4(2) Rp. 12.909.091,- (dua belas juta sembilan ratus sembilan ribu sembilan puluh satu rupiah) dan Pajak Pertambahan Nilai (PPN) Rp. 64.545.455,-- (enam puluh empat juta lima ratus empat puluh lima ribu empat ratus lima puluh enam rupiah) dengan total pajak Rp. 77.454.546,- (tujuh puluh tujuh juta empat ratus lima puluh empat ribu lima ratus empat puluh enam rupiah) kemudian jumlah yang dibayarkan menjadi Rp. 632.545.454,- (enam ratus tiga puluh dua juta lima ratus empat puluh lima ribu empat ratus lima puluh empat rupiah) dengan surat perintah pencairan dana dari bendahara umum daerah No: o174/PU/SP2DLS/2015 tanggal 28 Oktober 2015 yang ditandatangani bendahara umum daerah H. Irwan Sakti Nasution, S.H., M.AP.

b. Pembayaran termin I dan II 60\% sebesar Rp. 1.704.00o.00oo,- (satu miliar tujuh ratus empat juta rupiah) dan yang diterima rekanan setelah dipotong Pajak Penghasilan Ps 4(2) Rp. 30.981.818,- (tiga puluh juta sembilan ratus delapan puluh satu ribu delapan delapan belas rupiah) dan Pajak Pertambahan Nilai (PPN) Rp. 154.909.091,-- (seratus lima puluh empat juta sembilan ratus sembilan ribu sembilan puluh satu rupiah) dengan total pajak Rp. 185.890.909,- (seratus delapan puluh lima juta delapan ratus sembilan puluh ribu sembilan ratus sembilan rupiah) dengan surat perintah pencairan dana dari bendahara umum daerah No: 
0370/PU/SP2D-LS/2015 tanggal 28 Desember 2015 yang ditandatangani

bendahara umum daerah H. Irwan Sakti Nasution, S.H., M.AP;

Dasar pembuatan Surat Perintah Pembayaran Langsung (SPP-LS) Peraturan Menteri Dalam Negeri No. 13 Tahun 2006 tentang Pedoman Pengelolaan Keuangan Daerah;

- Bahwa dalam pembayaran pertama termin uang muka sebesar 20\% dan pembayaran termin I dan II 6o\% yang bertanggung jawab adalah saksi selaku bendahara pengeluaran yang membuat dan menerbitkan Surat Perintah Pembayaran Langsung (SPP-LS) kemudian Pejabat Pembuat Komitmen (PPK) yakni kepala dinas PU kota Tanjung Balai ZULKARNAIN AMRULLAH, S.T., yang melakukan penelitian Surat Perintah Pembayaran Langsung (SPP-LS) dan menerbitkan Surat Perintah Membayar Langsung (SPM-LS) sesuai Peraturan Menteri Dalam Negeri Nomor 13 Tahun 2006 tentang Pedoman Pengelolaan Keuangan Daerah;

- Bahwa mekanisme pembayarannya adalah masuknya permohonan pencairan oleh pihak rekanan PT. CARE INDONUSA yang kemudian di disposisi oleh Kepala Dinas selaku Pejabat Pembuat Komitmen (PPK) yang disertai adanya berita acara pembayaran, setelah itu dibuatkan Surat Permintaan Pembayaran Langsung (SPP-LS) kemudian semua dokumen tersebut diajukan kepada Dinas Pengelolaan Pendapatan Keuangan Aset Daerah (PPKAD) untuk permintaan pembayaran tersebut dan setelah Surat Perintah Membayar (SPM) disetujui oleh dinas PPKAD baru dibuatkan Surat Perintah Pencairan Dana $\left(\mathrm{SP}_{2} \mathrm{D}\right)$ nya yang mana uang permintaan pembayaran tersebut langsung dikirimkan ke rekening pihak rekanan PT. CARE INDONUSA atas nama DEDI HERMAWAN/Direktur PT. CARE INDONUSA atas nama DEDI HERMAWAN/Direktur PT. CARE INDONUSA pada Bank Sumut dengan nomor rekening 262.01.04.000468.2;

- Bahwa pada saat proses pencairan uang muka yakni pembayaran $20 \%$ dari nilai kontrak yang bertanda tangan adalah kepala dinas pekerjaan umum selaku Pejabat Pembuat Komitmen (PPK) yakni ZULKARNAIN AMRULLAH, S.T., dan pihak rekanan PT. CARE INDONUSA yang ditandatangani oleh Direktur An. DEDY HERMAWAN kemudian pada saat proses pembayaran sebesar $60 \%$ yang menandatangani proses pencairan yaitu:

a. Pertama diperiksa oleh pengawas lapangan yakni An. PADLAN, S.T., dan ANDRY KESUMA, S.T.

b. Kedua diperiksa oleh Pejabat Pelaksana Teknis Kegiatan (PPTK) KHAIRUDDIN, S.T.

c. Ketiga disetujui oleh Pejabat Pembuat Komitmen (PPK) ZULKARNAIN AMRULLAH, S.T.

d. Keempat ditandatangani oleh pihak kedua (rekanan) yakni Direktur perusahaan DEDY HERMAWAN PT. CARE INDONUSA. 
- Bahwa kemudian untuk Surat Permintaan Pembayaran Langsung (SPP-LS) ditandatangani oleh saksi selaku bendahara pengeluaran dan diketahui oleh Pejabat Pelaksana Teknis Kegiatan (PPTK) KHAIRUDDIN, S.T., kemudian Surat Perintah Membayar (SPM) ditandatangani oleh kepala dinas pekerjaan umum selaku Pejabat Pembuat Komitmen (PPK) KHAIRUDDIN, S.T., dan Surat Perintah Pencairan Dana (SP2D) ditandatangani oleh bendahara umum daerah $H$. IRWAN SAKTI NASUTION, S.H., M.AP;

- Bahwa dasarnya untuk melakukan pencairan adalah

a. Pembayaran pertama termin uang muka sebesar $20 \%$ adalah dilampirkannya bukti-bukti kontrak surat perjanjian pekerjaan, permohonan pencairan perusahaan, berita acara pembayaran termin uang muka sebesar $20 \%$, foto-foto dokumentasi kegiatan.

b. Pembayaran termin I dan II 6o\% adalah dilampirkannya bukti-bukti kontrak surat perjanjian pekerjaan, berita acara pembayaran termin $60 \%$, kemudian berita acara pemeriksaan prestasi pekerjaan, laporan kemajuan pelaksanaan pekerjaan dan permohonan pencairan perusahaaan sehingga setelah dokumen tersebut lengkap saksi membuat Surat Permintaan Pembayaran Langsung (SPP-LS) untuk diteruskan ke kepala dinas pekerjaan umum selaku Pejabat Pembuat Komitmen (PPK) untuk diterbitkan Surat Perintah Membayar (SPM).

- Bahwa addendum perjanjian (penambahan waktu) dan CCO (Contract Change Order) tidak mempengaruhi dalam proses pencairan dana dalam kegiatan ini. Karena syarat untuk dilakukannya pencairan dana hanya laporan kemajuan pelaksanaan pekerjaan dari Pejabat Pembuat Komitmen (PPK) dan Pejabat Pelaksana Teknis Kegiatan (PPTK);

- Bahwa dalam kegiatan ini tidak dilakukan pencairan $100 \%$ karena hanya dilakukan pencairan 2 (dua) yakni:

a. Pembayaran pertama termin uang muka sebesar $20 \%$ dari nilai kontrak yaitu Rp. 710.000.00o,- (tujuh ratus sepuluh juta rupiah) dan yang diterima rekanan setelah dipotong pajak penghasilan Ps 4(2) Rp. 12.909.091,- (dua belas juta sembilan ratus sembilan ribu sembilan puluh satu rupiah) dan Pajak Pertambahan Nilai (PPN) Rp. 64.545.455,- (enam puluh empat juta lima ratus empat puluh lima ribu empat ratus lima puluh lima rupiah) dengan total pajak Rp. 77.454.546,- (tujuh puluh tujuh juta empat ratus lima puluh empat ribu lima ratus empat puluh enam rupiah) kemudian jumlah yang dibayarkan menjadi Rp. 632.545.454,- (enam ratus tiga puluh dua juta lima ratus empat puluh enam rupiah) dengan surat perintah pencairan dana dari bendahara umum daerah No: 0174/PU/SP2D-LS/2015 tanggal 28 Oktober 2015 yang ditandatangani bendahara umum daerah H. Irwan Sakti Nasution, S.H., M.AP. 
b. Pembayaran termin I dan II 60\% sebesar Rp. 1.704.00o.ooo,- (satu miliar tujuh ratus empat juta rupiah) dan yang diterima rekanan setelah dipotong pajak penghasilan Ps. 4(2) Rp. 30.981.818,- (tiga puluh juta sembilan ratus delapan puluh satu ribu delapan delapan belas rupiah) dan Pajak Pertambahan Nilai (PPN) Rp. 154.909.091,-- (seratus lima puluh empat juta sembilan ratus sembilan puluh satu rupiah) dengan total pajak Rp. 185.890.909,- (seratus delapan puluh lima juta delapan ratus sembilan puluh ribu sembilan ratus sembilan rupiah) dengan surat perintah pencairan dana dari bendahara umum daerah No: 0370/PU/SP2D-LS/2015 tanggal 28 Desember 2015 yang ditandatangani bendahara umum daerah H. Irwan Sakti Nasution, S.H., M.AP. Sehingga total pencairan yang sudah dicairkan dalam kegiatan lanjutan pembangunan rumah sakit type $C$ kota Tanjung Balai T.A. 2015 adalah Rp. 2.414.000.00o,- (dua miliar empat ratus empat belas rupiah).

- Bahwa kegiatan lanjutan pembangunan rumah sakit type $C$ kota Tanjung Balai T.A. 2015 belum selesai dikerjakan karena pencairan dana baru mencapai $60 \%$ dan belum diserah terimakan kepada dinas pekerjaan umum kota Tanjung Balai;

- Bahwa atas keterangan saksi tersebut Terdakwa membenarkannya.

\section{Barang Bukti:}

Bahwa di persidangan Penuntut Umum mengajukan barang bukti sebagai berikut:

1. Dokumen Pelaksanaan Anggaran (DPA) T.A. 2015;

2. Dokumen Perubahan Pelaksanaan Anggaran (DPPA) T.A. 2015;

3. Rencana Kerja Anggaran (RKA) T.A. 2015 Dinas PU;

4. SK Penetapan PPK terkait lampiran SK Pengguna Anggaran Nomor 050/27a/K/2015 tanggal 24 Februari 2015;

5. SK Penetapan PPTK lampiran SK Pengguna Anggaran Nomor 050/27a/K/2015 tanggal 24 Februari 2015;

6. SK Penetapan Pokja pada Dinas PU, tanggal zo Maret 2015.

Dalam pertimbangan Putusan Nomor 15/Pid.Sus.TPK/2018/PN.Mdn. Hakim memberi dasar pertimbangan atas dakwaan yang diajukan tersebut adalah bersifat primair dan subsidair sehingga Majelis Hakim memilih langsung untuk dakwaan yang mendekati fakta pembuktian di persidangan yaitu dakwaan Primair sebagaimana diatur dalam Pasal 2 ayat (1) jo. Pasal 18 Undang-Undang Nomor 31 Tahun 1999 jo. Undang-Undang Nomor 20 Tahun 2001 tentang perubahan atas Undang-Undang Nomor 31 Tahun 1999 tentang Pemberantasan Tindak Pidana Korupsi yang unsur-unsurnya adalah sebagai berikut:

1. Setiap orang;

2. Secara melawan hukum;

3. Memperkaya diri sendiri, orang lain atau suatu korporasi;

4. Yang dapat merugikan keuangan negara atau perekonomian negara; 
5. Mereka yang melakukan, yang menyuruh melakukan dan yang turut serta melakukan tindak pidana itu.

\section{Ad. 1. Unsur Setiap Orang}

Menimbang, bahwa pengertian setiap orang adalah siapa saja. Siapa saja dapat juga diartikan sebagai barang siapa dan dalam ajaran hukum pidana adalah menunjuk subyek dari strafbaarfeit (perbuatan pidana), sehingga yang dianggap sebagai subyek dari strafbaarfeit tersebut hanya natuurlijk persoon (manusia hidup);

Menimbang, bahwa pelaku dari tindak pidana di dalam Pasal 2 ayat (1) jo. Pasal 18 Undang-Undang Nomor 20 Tahun 2001 jo. Pasal 55 KUHP ayat (1) ke-1 KUHP telah ditentukan "setiap orang" sesuai dengan ketentuan Pasal 1 angka 3 Undang-Undang Nomor 20 Tahun 2001 yang dimaksud setiap orang adalah orang perorangan atau korporasi;

Menimbang, bahwa tentang "barang siapa" bila dikaji dari aspek teoritik dan praktek peradilan, maka pada hakekatnya ada 2 (dua) pandangan yang saling bertolak belakang tentang eksistensi anasir "barang siapa" sebagai bestanddelen dari delik. Disatu sisi ada pandangan yang menyatakan bahwa anasir "barang siapa" itu ada dengan sendirinya pada setiap tindak pidana, sehingga tidak perlu dibuktikkan lagi. Sedangkan pandangan lain berasumsi bahwa kata "barang siapa" merupakan bestanddelen dari delik, dengan alasan bahwa hal yang membedakan fungsi pertanggungjawaban yang harus dibuktikan karena kalaupun ada tindak pidana, maka harus dibuktikan siapa yang bertanggung jawab untuk dijatuhi pidana;

Menimbang, bahwa undang-undang tidak mensyaratkan adanya sifat tertentu yang harus dimiliki dari seorang pelaku, dengan demikian pengertian "setiap orang" atau siapa saja berlaku terhadap siapapun dalam arti unsur setiap orang yang meliputi subyek hukum, baik perorangan maupun badan hukum dan perkembangan baru yang diatur dalam UndangUndang Nomor 20 Tahun 2001 ini korporasi pun telah masuk sebagai subyek tindak pidana korupsi yang dapat dikenakan sanksi atau yang diancam pidana dengan undang-undang yang dilakukan seseorang yang dapat dipertanggungjawabkan (toerekenings vat baarheid);

Menimbang, bahwa dari fakta-fakta hukum Terdakwa mengaku bernama Dedi Hermawan merupakan orang yang bertanggung jawab atas kegiatan tersebut dan saksi juga membenarkan identitas Terdakwa adalah benar sebagai orang yang dapat dimintai pertanggungjawaban pidana, dikarenakan tidak ada alasan pemaaf maupun pembenar pada diri Terdakwa yang dapat membebaskan atau melepaskan Terdakwa dari tuntutan pidana.

\section{Ad. 2. Unsur Secara Melawan Hukum}

Menimbang, bahwa dalam penjelasan Pasal 2 ayat (1) Undang-Undang Nomor 20 Tahun 2001 menyebutkan bahwa yang dimaksud dengan "secara melawan hukum" mencakup perbuatan melawan hukum dalam arti formil maupun dalam arti materiil, yakni meskipun perbuatan tersebut tidak diatur dalam peraturan perundang-undangan. Namun, apabila perbuatan tersebut kehidupan sosial dalam masyarakat, maka perbuatan tersebut dapat dipidana;

Menimbang, bahwa dengan adanya kata "maupun" dalam penjelasan tersebut, dapat diketahui bahwa Undang-Undang Nomor 20 Tahun 2001 mengikuti 2 (dua) ajaran sifat 
melawan hukum secara alternatif (Roeslan Saleh dalam buku R Wiyono berjudul pembahasan Undang-Undang Pemberantasan Tindak Pidana Korupsi), yaitu:

a. Ajaran sifat melawan hukum formil berpendapat bahwa melawan hukum adalah bertentangan dengan hukum tertulis saja.

b. Ajaran sifat melawan hukum materiil berpendapat bahwa melawan hukum materiil tidaklah hanya sekedar bertentangan dengan hukum tertulis, tetapi juga bertentangan dengan hukum tidak tertulis. Yang berarti disamping memenuhi syarat-syarat formil, perbuatan harus benar-benar dirasakan masyarakat sebagai tidak boleh atau tidak patut.

Menimbang, bahwa dengan lahirnya putusan Mahkamah Konstitusi Republik Indonesia Nomor: 03/PUU-IV/2006 tanggal 25 Juli 2006 menyiratkan harus perbuatan melawan hukum formil, artinya harus bertentangan dengan ketentuan yang tertulis, pertimbangan hakim MK adalah penjelasan Pasal 2 ayat (1) Undang-Undang Nomor 20 Tahun 2001 mengenai perbuatan melawan hukum dalam arti materiil telah dinyatakan bertentangan dengan Undang-Undang Dasar NRI 1945 dan telah pula dinyatakan tidak mempunyai kekuatan hukum mengikat.

\section{Ad. 3. Unsur "Memperkaya diri sendiri, orang lain atau suatu korporasi"}

Menimbang, bahwa yang dimaksudkan dalam unsur ini adalah timbulnya niat dari pelaku untuk melakukan perbuatan tersebut demi kepentingan diri sendiri atau orang lain sehingga dapat merubah kondisi kehidupannya, dengan memperhatikan perumusan ketentuan tentang tindak pidana korupsi seperti yang terdapat dalam Pasal 2 ayat (1), dapat diketahui bahwa unsur "melawan hukum" dari ketentuan tentang tindak pidana korupsi tersebut merupakan sarana untuk melakukan perbuatan memperkaya diri sendiri atau orang lain atau korporasi;

Menimbang, bahwa yang dimaksud dengan "memperkaya" adalah perbuatan yang dilakukan untuk menjadi lebih kaya (lagi) dan perbuatan ini sudah tentu dapat dilakukan dengan bermacam-macam cara misalnya: menjual/membeli, menandatangani kontrak, memindahbukukan dalam bank, dengan syarat tentunya dilakukan dengan melawan hukum, jika akan dikualifikasikan sebagai tindak pidana korupsi sebagaimana maksud dalam Pasal 2 ayat (1);

Menimbang, bahwa berdasarkan uraian doktrin tentang pengertian unsur "memperkaya" sebagaimana yang telah disebutkan di atas, dihubungkan dengan fakta yuridis yang terungkap dipersidangan berdasarkan keterangan saksi-saksi, keterangan ahli, dan barang bukti, maka dapat dibuktikan fakta perbuatan Terdakwa yang menerangkan:

- Bahwa Terdakwa telah melakukan pencairan terhhadap kegiatan ini sebanyak 2 (dua) kali yakni:

a. Berita acara pembayaran termin muka $20 \%$ No. 900/396/PPSPRSPU/APBD/2015 dari nilai kontrak.

b. Berita acara pembayaran termin I dan II (60\%) uang muka $20 \%$ pencairan pada saat progress pekerjaan $60 \%$ dan dasar pencairan adalah sudah mencapai fisik 70\% yang dituangkan dalam laporan kemajuan pelaksanaan pekerjaan yakni 70,o1\%.

\section{Ad. 4. Unsur "Yang dapat merugikan keuangan negara atau perekonomian negara" Pertanggungjawaban Pidana Direktur Perseroan Terbatas Dalam Tindak Pidana Korupsi Proyek Terbatas Dalam Tindak Pidana Korupsi Proyek Pembangunan Rumah Sakit (Studi Putusan No. 15/Pid.Sus- TPK/2018/PN.Mdn)}


Menimbang, bahwa kata dapat sebelum frasa "merugikan keuangan negara atau perekonomian negara" menunjukan bahwa tindak pidana korupsi merupakan delik formil yaitu adanya tindak pidana korupsi cukup dengan timbulnya akibat, dengan demikian dari rumusan tersebut kerugian negara tidaklah mutlak/harus telah terjadi. Namun, juga dapat dikenakan terhadap kerugian negara yang belum terjadi tetapi perbuatan melawan hukum yang dilakukan tersebut sudah berpotensi akan dapat menimbulkan kerugian negara atau perekonomian negara;

Menimbang, bahwa berdasarkan penjelasan umum Undang-Undang Nomor 20 Tahun 2001 yang dimaksud dengan keuangan negara adalah seluruh kekayaan negara dalam bentuk apapun yang dipisahkan atau yang tidak dapat dipisahkan segala bagian kekayaan negara dan segala hak dan kewajiban yang timbul karena:

- Berada dalam penguasaan, pengurusan, dan pertanggungjawaban pejabat negara baik ditingkat pusat maupun daerah;

- Berada dalam penguasaan, pengurusan, dan pertanggungjawaban Badan Usaha Milik Negara/ Badan Usaha Milik Daerah, Yayasan, badan hukum, dan perusahaan yang menyertakan modal pihak ketiga berdasarkan perjanjian dengan negara.

Sedangkan yang dimaksud dengan perekonomian negara adalah kehidupan perekonomian negara yang disusun sebagai usaha bersama berdasarkan asas kekeluargaan ataupun usaha masyarakat secara mandiri yang didasarkan pada kebijakan pemerintah, baik ditingkat pusat maupun di daerah sesuai dengan ketentuan peraturan perundang-undangan yang berlaku yang bertujuan memberikan manfaat, kemakmuran, dan kesejahteraan kepada seluruh kehidupan masyarakat.

Menimbang, bahwa akibat dari perbuatan melawan hukum yang dilakukan oleh Terdakwa, berdasarkan laporan hasil pemeriksaan investigatif dalam rangka penghitungan kerugian negara atas pekerjaan lanjutan pembangunan rumah sakit type $C$ kota Tanjung Balai T.A. 2015 34/LHP/XXI/11/2017 tanggal 13 November 2017 dan keterangan ahli Yuli Rahman, S.T., CfrA., ahli penghitungan negara yang menerangkan:

Bahwa perbuatan Terdakwa yang menyimpang dari ketentuan yang seharusnya yaitu:

1) Penyimpangan dalam pemilihan penyedia jasa berupa:

a) Adanya dugaan persaingan tidak sehat dalam proses lelang.

b) Surat keterangan dukungan Bank untuk PT. Care Indonusa tidak diakui Bank Sumut.

\section{Ad. 5. Unsur "Mereka yang melakukan, yang menyuruh melakukan dan yang turut serta melakukan tindak pidana itu".}

Menimbang, bahwa jelas makna dari istilah penyertaan (deelneming) ialah dua orang atau lebih yang melakukan tindak pidana atau dengan lain perkataan ada dua orang atau lebih mengambil bagian untuk mewujudkan suatu tindak pidana. (E.Y Kenter, S.H., dan S.R. Sianturi, S.H., asas-asas hukum pidana di Indonesia dan penerapannya);

Menimbang, bahwa yang dimaksud dengan "pelaku" (dader) adalah orang yang memenuhi semua unsur delik sebagaimana dirumuskan oleh undang-undang, baik unsur subjektif maupun unsur objektif; 
Menimbang, bahwa dader dalam pengertian luas adalah yang dimuat dalam MvT pembentukan Pasal 55 KUHP, yang diantara lain mengutarakan:

"yang harus dipandang sebagai dader itu bukan saja mereka yang telah menggerakkan orang lain untuk melakukan delik melainkan juga mereka yang telah menyuruh melakukan dan mereka yang turut melakukan";

Menimbang, bahwa berdasarkan uraian doktrin tentang pengertian unsur "dader dan doen pleger" sebagaimana yang telah disebutkan diatas, dihubungkan dengan fakta yuridis yang terungkap dipersidangan berdasarkan keterangan saksi-saksi, keterangan ahli, dan barang bukti, maka dapat dibuktikan fakta perbuatan Terdakwa:

- Bahwa Terdakwa melakukan permintaan dan penyusunan Change Contract Order (CCO) tidak didukung dengan hasil pengukuran/perhitungan teknik dan usulan dari penyedia jasa.

- Bahwa Terdakwa tidak mengusulkan pengukuran/penghitungan teknik sebagai dasar CCO atas kontrak dan PPK menyetujui dan menandatangani CCO yang tidak memiliki pengukuran/perhitungan teknik dan usulan dari penyedia jasa.

- Bahwa Terdakwa mengajukan pembayaran termin 6o\% atas kemajuan pekerjaan pada tanggal 18 Desember 2015, meskipun volume pekerjaan terpasang tidak sesuai dengan kondisi senyatanya dan PPK kemudian menerbitkan surat perintah membayar (SPM) dalam rangka pembayaran termin 6o\% tanggal 18 Desember 2015 kepada Sdr. Dedi Hermawan (Direktur PT. Care Indonusa).

- Bahwa Terdakwa belum menyerahkan hasil pekerjaan kepada pihak Dinas PU kota Tanjung Balai sebagai pengguna barang/jasa atau owner; dan

- Bahwa Terdakwa tidak melaksanakan pekerjaan sesuai volume yang diatur dalam kontrak.

Keadaan yang memberatkan:

- Terdakwa tidak mendukung program pemerintah dalam memberantas tindak pidana korupsi.

\section{Keadaan yang meringankan:}

- Terdakwa belum pernah di hukum.

- Terdakwa berperilaku sopan dan jujur dipersidangan.

- Terdakwa memiliki tanggungan keluarga.

\section{E. Putusan Hakim}

1. Menyatakan Terdakwa terbukti secara sah dan meyakinkan bersalah melakukan tindak pidana "korupsi" sebagaimana didakwa dalam dakwaan primair;

2. Menjatuhkan pidana kepada Terdakwa oleh karena itu dengan pidana penjara selama 5 (lima) tahun dan 6 (enam) bulan dan denda sejumlah Rp. 200.00o.ooo,(dua ratus juta rupiah) dengan ketentuan apabila denda tersebut tidak bayar diganti dengan pidana kurungan selama 4 (empat) bulan;

3. Menghukum Terdakwa untuk membayar uang pengganti sebesar Rp. 1.013.887.298.19,- (satu miliar tiga belas juta delapan ratus tujuh puluh tujuh ribu dua ratus sembilan puluh delapan ribu sembilan belas rupiah); jika Terdakwa tidak sanggup membayar uang pengganti paling lama dalam waktu 1 (satu) bulan sesudah 
putusan pengadilan yang berkekuatan hukum tetap, maka harta bendanya dapat disita oleh Jaksa dan dilelang untuk menutupi uang pengganti tersebut, dalam hal Terdakwa tidak mempunyai harta benda yang mencukupi untuk membayar uang pengganti, maka akan diganti dengan pidana penjara selama 1 (satu) tahun penjara;

4. Menetapkan masa penahanan yang telah dijalani Terdakwa dikurangkan seluruhnya dari pidana yang dijatuhkan;

5. Memerintahkan masa penahanan yang telah dijalani Terdakwa dikurangkan seluruhnya dari pidana yang dijatuhkan;

6. Menyatakan barang bukti berupa:

- Dokumen Pelaksanaan Anggaran (DPA) T.A. 2015;

- Dokumen Perubahan Pelaksanaan Anggaran (DPPA) T.A. 2015;

- Rencana Kerja Anggaran (RKA) T.A. 2015 Dinas PU;

- SK Penetapan PPK terkait lampiran SK pengguna anggaran nomor 050/276a/K/2015 tanggal 24 Februari 2015;

- SK Penetapan PPTK lampiran SK pengguna anggaran nomor 050/276a/K/2015 tanggal 24 Februari 2015;

- Dokumen HPS;

- Dokumen Rencana Anggaran Biaya.

7. Membebankan kepada Terdakwa membayar biaya perkara sejumlah Rp. 5.ooo,- (lima ribu rupiah).

\section{F. Analisis Kasus}

\section{Dakwaan}

Surat dakwaan adalah surat atau akta yang memuat tindak pidana yang didakwakan kepada Terdakwa yang disimpulkan dan ditarik dari hasil pemeriksaan penyidikan, dan merupakan dasar serta landasan bagi Hakim dalam pemeriksaan di muka sidang pengadilan. ${ }^{7}$ Surat dakwaan disusun sesuai dengan isi secara cermat, jelas, dan lengkap sesuai dengan syarat formil dan meteriil yang diatur dalam Pasal 143 (2) a dan b KUHAP. Ada beberapa macam bentuk surat dakwaan yang dapat dibuat oleh Jaksa Penuntut Umum untuk mendakwa seseorang Terdakwa kepada Hakim di muka sidang pengadilan yaitu:

a. Surat dakwaan tunggal

Dalam surat dakwaan ini hanya satu tindak pidana saja yang di dakwakan, karena tidak terdapat kemungkinan untuk mengajukan alternatif atau dakwaan pengganti lainnya.

b. Surat dakwaan alternatif

Dalam surat dakwaan ini terdapat beberapa dakwaan yang disusun secara berlapis, lapisan yang satu merupakan alternatif dan bersifat mengecualikan dakwaan pada lapisan lainnya. Bentuk dakwaan ini digunakan bila belum di dapat kepastian tentang tindak pidana mana yang paling tepat dapat dibuktikan. Dalam dakwaan alternatif, meskipun dakwaan terdiri dari beberapa lapisan, hanya satu dakwaan saja yang dibuktikan tanpa harus memperhatikan urutannya dan jika salah satu telah terbukti maka dakwaan pada lapisan lainnya tidak perlu dibuktikan lagi. Dalam

${ }^{7}$ M. Yahya Harahap, Pembahasan Permasalahan dan Penerapan KUHAP Penyidikan dan Penuntutan, Jakarta, Sinar Grafika, 2013, hlm. 386-387. 
Jurnal Magister Hukum Program Pascasarjana Universitas HKBP Nommensen

Volume 02 Nomor o1 Januari 2021 Halaman. 103-132 e-ISSN: 2723-164X p-ISSN: 2722-9858

http://ejournal.uhn.ac.id/index.php/opinion

bentuk surat dakwaan alternatif antara lapisan satu dengan yang lainnya menggunakan kata sambung "atau".

c. Surat dakwaan subsidair

Sama halnya dengan dakwaan alternatif, dakwaan subsidair juga terdiri dari beberapa lapisan dakwaan yang disusun secara berlapis dengan maksud lapisan yang satu berfungsi sebagai pengganti lapisan sebelumnya. Sistematik lapisan disusun berurut dimulai dari tindak pidana yang diancam dengan pidana tertinggi sampai dengan tindak pidana yang diancam dengan pidana terendah.

Pembuktian dalam surat dakwaan ini harus dilakukan secara berurut dimulai dari lapisan teratas sampai dengan lapisan selanjutnya. Lapisan yang tidak terbukti harus dinyatakan secara tegas dan dituntut agar terdakwa di bebaskan dari lapisan dakwaan yang bersangkutan.

d. Surat dakwaan kumulatif

Dalam surat dakwaan ini, di dakwakan beberapa tindak pidana sekaligus, ke semua dakwaan harus dibuktikan satu demi satu. Dakwaan yang tidak terbukti harus dinyatakan secara tegas dan dituntut pembebasan dari dakwaan tersebut. Dakwaan ini dipergunakan dalam hal terdakwa melakukan beberapa tindak pidana yang masing-masing merupakan tindak pidana yang berdiri sendiri.

e. Surat dakwaan kombinasi

Dalam surat dakwaan ini disebut dakwaan kombinasi, karena di dalam bentuk ini dikombinasikan atau digabungkan antara dakwaan kumulatif dengan dakwaan alternatif dan subsidair.

Jaksa Penuntut Umum mendakwa Terdakwa dengan dakwaan primair melanggar Pasal 2 ayat (1) jo. Pasal 18 ayat (1) b Undang-Undang Nomor 20 Tahun 2001 tentang Pemberantasan Tindak Pidana Korupsi jo. Pasal 55 ayat (1) ke-1 KUHP dan dakwaan subsidair melanggar Pasal 3 jo. Pasal 18 ayat (1) Undnag-Undang Nomor 20 Tahun 2001 tentang Pemberantasan Tindak Pidana Korupsi jo. Pasal 55 ayat (1) ke-1 KUHP.

Terhadap pasal-pasal dakwaan diatas penulis sependapat dengan surat dakwaan Jaksa Penuntut Umum dalam bentuk primair karena perbuatan terdakwa adalah untuk memperkaya diri sendiri dan tergolong untuk kepentingan individu Direktur. Perbuatan terdakwa Dedi Hermawan tergolong terpisah dari kepentingan perseroan, sebab uang hasil tindak pidana korupsi tersebut hanya masuk ke dalam rekening pribadi Direktur perseroan dan tidak masuk ke dalam rekening perusahaan itu sendiri. Sehingga perbuatan terdakwa tergolong perbuatan yang memperkaya diri sendiri atau orang lain yakni Zulkarnain Amrullah yang berkasnya terpisah. Perbuatan terdakwa Dedi Hermawan selaku Direktur juga telah merugikan keuangan negara sebesar Rp. 1.013.877.289.19,- (satu miliar tiga belas juta delapan ratus tujuh puluh tujuh ribu dua ratus delapan puluh sembilan koma sembilan belas rupiah). Atas perbuatan terdakwa tersebut maka Jaksa Penuntut Umum dalam dakwaannya memasukkan perbuatan terdakwa ke dalam Pasal 2 Undang-Undang Nomor 20 Tahun 2001 tentang Pemberantasan Tindak Pidana Korupsi, dimana terdakwa sendiri merupakan Direktur di Perseroan Terbatas 'swasta' yang memiliki korelasi dengan kedudukan atau jabatan terdakwa sebagai Direktur di perseroan swasta. Menurut hemat penulis dakwaan subsidair Pasal 3 Undang-Undang Nomor 20 Tahun 2001 tidak tepat di dakwakan terhadap terdakwa sebab terdakwa sendiri merupakan Direktur BUMS sehingga hal tersebut dapat membuat terdakwa nantinya terlepas dari penegakan hukum. Disisi lain, Perbuatan terdakwa yang dilakukan secara melawan hukum dimana perbuatan tersebut tidak lurus dengan ketentuan perundang-undangan yang berlaku. Dalam 
dakwaan primairnya Jaksa Penuntut Umum juga mendakwakan Pasal 18 Undang-Undang Nomor 20 Tahun 2001 dikarenakan akibat dari perbuatan terdakwa yang mengakibatkan kerugian negara, sehingga atas perbuatan itu diperlukannya pidana tambahan sebagai upaya pemulangan sebagian atau seluruh aset kerugian negara dari hasil tindak pidana korupsi yang dilakukan oleh Terdakwa. Penulis juga berpendapat bahwa dakwaan Jaksa Penuntut Umum sesuai dengan teori kausalitas yakni suatu akibat tertentu terkadang ditimbulkan oleh serangkaian perbuatan yang saling terkait menjadi faktor-faktor yang menyebabkan timbulnya suatu akibat, akibat disini diartikan sebagai pertanggungjawaban dari Direktur PT. Care Indonusa atas perbuatan tindak pidana korupsi yang diperbuatnya dan pada kasus ini tidak ditemukannya alasan pemaaf maupun alasan pembenar pada diri terdakwa Dedi Hermawan sehingga Jaksa Penuntut Umum menjatuhkan dakwaan kepada Direktur PT. Care Indonusa dengan dakwaan primair dan subsidair.

Bila melihat kepada teori pertanggungjawaban Direktur Perseroan Terbatas yakni fiduciary duty yang lahir dari suatu hubungan fidusia. Tidak semua orang bisa mendapatkan suatu kewajiban fidusia, kecuali orang itu mempunyai kemampuan fidusia, yaitu kemampuan untuk memegang dan melaksanakan amanah dari pihak lain berkenan dengan suatu hal, mengurus dan menjalankannya, untuk kepentingan si pemberi amanah. Sehingga melalui ikatan untuk memegang dan melaksanakan amanah dari pihak lain tersebut Direktur diharuskan untuk menjalankan perseroan dengan itikad baik dan sesuai ketentuan anggaran dasar perusahaan. Bilamana terdapat pelanggaran yang hanya dilakukan oleh Direktur dan perseroan tidak memiliki kesalahan maka pertanggungjawaban hanyalah dimintakan terhadap Direktur perseroan karena dengan dasar hubungan fidusia tersebut dan Direktur selaku persona standi in judicio atau subyek hukum mandiri. Sehingga tepatlah dakwaan dari Jaksa Penuntut Umum terhadap Direktur PT. Care Indonusa karena pada kasus tindak pidana korupsi tersebut dilakukan oleh Direktur dan perseroan tidak terlibat di dalamnya sebab uang hasil korupsi tersebut tidak masuk ke dalam rekening perseroan dan perseroan sendiri pun tidak ikut menikmati uang hasil tindak pidana korupsi tersebut.

\section{Tuntutan}

Penuntut Umum dalam melakukan penuntutan, dapat dimaknai secara etimologis, dimana Penuntut Umum berasal dari kata prosecutor yang menjalankan fungsi prosecution. Prosecution berasal dari bahasa latin prosecutus, prosecutus terdiri dari kata pro (sebelum) dan sequi (mengikuti), yang dapat dipahami sebagai tugas untuk menggendalikan proses perkara dari awal hingga berakhir. ${ }^{8}$

Dalam Pasal 1 ayat (7) KUHAP memberikan pengertian penuntutan adalah tindakan penuntut umum untuk melimpahkan perkara pidana ke pengadilan negeri yang berwenang dalam hal dan menurut cara yang diatur dalam undang-undang ini untuk melakukan penuntutan dan melaksanakan penetapan Hakim.

Dalam hukum acara pidana tugas Jaksalah untuk membuktikan adanya kesalahan yang dilakukan oleh Terdakwa Dedi Hermawan, dalam tuntutannya Penuntut Umum menentukan dengan dakwaan yang disusun secara primair dan subsidair. Tuntutan Jaksa Penuntut Umum menyatakan terdakwa Dedi Hermawan bersalah melanggar tindak pidana korupsi sebagaimana diatur dan diancam pidana dalam Pasal 2 ayat (1) jo. Pasal 18 ayat (1) b UndangUndang Nomor 20 Tahun 2001 tentang Pemberantasan Tindak Pidana Korupsi jo. Pasal 55 ayat (1) ke-1 KUHP dan menjatuhkan pidana penjara kepada Terdakwa Dedi Hermawan selama 6 (enam) tahun dan denda Rp. 200.00o.ooo,- (dua ratus juta rupiah) dengan ketentuan apabila

\footnotetext{
${ }^{8}$ Aristo M. A. Pangaribuan et al., Pengantar Hukum Acara Pidana di Indonesia, Jakarta, Rajawali Pers, 2017 , hlm. 111. Pertanggungjawaban Pidana Direktur Perseroan Terbatas Dalam Tindak Pidana Korupsi Proyek Terbatas Dalam Tindak Pidana Korupsi Proyek Pembangunan Rumah Sakit (Studi Putusan No. 15/Pid.SusTPK/2018/PN.Mdn)
} 
denda tidak dibayar maka diganti 4 (empat) bulan kurungan dan Terdakwa dibebankan membayar uang pengganti Rp. 1.337.442.298,- (satu miliar tiga ratus tiga puluh tiga tujuh juta empat ratus empat puluh dua ribu dua ratus sembilan puluh delapan rupiah) jika Terdakwa tidak sanggup membayar uang pengganti paling lama dalam waktu 1 (satu) bulan sesudah putusan pengadilan yang berkekuatan hukum tetap, maka harta bendanya dapat disita oleh Jaksa dan dilelang untuk menutupi uang pengganti tersebut, dalam hal Terdakwa tidak mempunyai harta benda yang mencukupi untuk membayar uang pengganti, maka akan diganti dengan pidana penjara selama 1 (satu) tahun penjara.

Terhadap penjelasan diatas, penulis sependapat dengan tuntutan Jaksa Penuntut Umum yang diajukan pada sidang Pengadilan Negeri Medan tepatnya pada tuntutan Jaksa Penuntut Umum menyatakan terdakwa Dedi Hermawan bersalah melanggar tindak pidana korupsi sebagaimana diatur dan diancam pidana dalam Pasal 2 ayat (1) jo. Pasal 18 ayat (1) b UndangUndang Nomor 20 Tahun 2001 tentang Pemberantasan Tindak Pidana Korupsi jo. Pasal 55 ayat (1) ke-1 KUHP dan menjatuhkan pidana penjara kepada Terdakwa Dedi Hermawan selama 6 (enam) tahun. Alasan penulis adalah karena pada tindak pidana korupsi tersebut terdakwa telah melakukan "kesalahan" sebagai dasar dapat dimintakannya pertanggungjawaban pidana terhadap terdakwa Dedi Hermawan. Kesalahan yang dilakukan oleh terdakwa Dedi Hermawan selaku Direktur PT. Care Indonusa yakni perbuatan murni untuk memperkaya diri sendiri atau orang lain yakni Zulkarnain Amrullah yang berkasnya terpisah, karena uang hasil tindak pidana korupsi tersebut hanya masuk ke dalam rekening Direktur dan tidak masuk kedalam rekening perseroan sehingga perbuatan terdakwa adalah untuk kepentingan individu. Bila merujuk kepada unsur-unsur kesalahan dalam hukum pidana yakni adanya kemampuan bertanggung jawab pada si pelaku, adanya hubungan bantin antara si pelaku dengan perbuatannya baik disengaja (dolus) maupun karena kealpaan (culpa) dan tidak adanya alasan pemaaf yang dapat menghapus kesalahan. Akibat perbuatan atau kesalahan tindak pidana korupsi yang dilakukan secara individu oleh terdakwa Dedi Hermawan telah merugikan keuangan negara sehingga menjadi dasar penjatuhan tuntutan pidana terhadap terdakwa Dedi Hermawan. Tindakan dari Dedi Hermawan tersebut juga tidak sejalan dengan prinsip good corporate governance yakni mekanisme pengelolaan perusahaan berlandaskan peraturan perundang-undangan dan etika berusaha. Namun, terhadap beberapa tuntutan Jaksa Penuntut Umum penulis tidak sependapat yakni terhadap tuntutan denda Rp. 200.000.00o,- (dua ratus juta rupiah) dengan ketentuan apabila denda tidak dibayar maka diganti 4 (empat) bulan kurungan dan Terdakwa dibebankan membayar uang pengganti Rp. 1.337.442.298,- (satu miliar tiga ratus tiga puluh tiga tujuh juta empat ratus empat puluh dua ribu dua ratus sembilan puluh delapan rupiah) jika Terdakwa tidak sanggup membayar uang pengganti paling lama dalam waktu 1 (satu) bulan sesudah putusan pengadilan yang berkekuatan hukum tetap, maka harta bendanya dapat disita oleh Jaksa dan dilelang untuk menutupi uang pengganti tersebut, dalam hal Terdakwa tidak mempunyai harta benda yang mencukupi untuk membayar uang pengganti, maka akan diganti dengan pidana penjara selama 1 (satu) tahun penjara. Menurut hemat penulis suatu denda yang nantinya jika tidak mampu dibayar oleh terdakwa diganti dengan kurungan tidak lah relevan dengan klasifikasi tindak pidana korupsi sebagai kejahatan luar biasa (extra ordinary crime) yang mana penanganannya juga membutuhkan penanganan yang luar biasa. Oleh sebab itu, penulis menekankan pentingnya kecermatan kepada penuntutan agar penjatuhan tuntutan terhadap terdakwa sebaiknya maksimal agar menimbulkan efek jera dan memulangkan seluruh kerugian negara yang telah diperbuat oleh terdakwa.

Dalam keterkaitan kasus tindak pidana korupsi ini dengan teori pertanggungjawaban Pidana Direktur Perseroan Terbatas dikenal teori fiducia yang artinya "kepercayaan" atau 
"trust", atau dengan kata kerja fidere, yang berarti "mempercayai" atau "to trust". Istilah "fiduciary" diartikan "memegang sesuatu dalam kepercayaan" atau "seseorang yang memegang sesuatu dalam kepercayaan untuk kepentingan orang lain". Pemegang sesuatu secara kepercayaan untuk kepentingan orang lain disebut "trustee". Sehingga menurut hemat penulis dalam Putusan Nomor 15/Pid.Sus-TPK/2018/PN.Mdn., yang dapat dimintakan pertanggungjawaban pidananya hanyalah Direktur saja. Sebab uang hasil korupsi tersebut masuk ke dalam rekening Dedi Hermawan selaku Diretur dan tidak masuk ke dalam rekening PT. Care Indonusa artinya tidak terdapat unsur kesalahan di dalam perseroan tersebut dan tidak dapatnya dimintakan pertanggungjawaban pidana. Oleh sebab itu, tuntutan pidana hanyalah dimintakan kepada terdakwa Dedi Hermawan selaku Direktur PT. Care Indonusa mengingat keberadaan Direktur sebagai persona standi in judicio atau subyek hukum mandiri yang telah melakukan perbuatan secara melawan hukum berupa tindak pidana korupsi.

\section{Dasar Pertimbangan Hakim terhadap Putusan Pengadilan Negeri Medan Nomor 15/Pid.Sus.TPK/2018/PN.Mdn.}

Hakim dalam mempertimbangkan berdasarkan kerterangan saksi, keterangan terdakwa, keterangan ahli, dan barang bukti yang dihadirkan di muka persidangan. Memperhatikan susunan dakwaan yang demikian terlihat bahwa dakwaan yang diajukan tersebut adalah bersifat primair dan subsidair sehingga Majelis Hakim akan memilih langsung dakwaan yang mendekati fakta pembuktian di persidangan yaitu dakwaan primair sebagaimana diatur dalam Pasal 2 ayat (1) jo. Pasal 18 ayat (1) Undang-Undang Nomor 20 Tahun 2001 tentang Pemberantasan Tindak Pidana Korupsi jo. Pasal 55 ayat (1) ke-1 KUHP yang unsur-unsurnya adalah sebagai berikut:

1. Unsur setiap orang;

2. Unsur secara melawan hukum;

3. Unsur memperkaya diri sendiri, orang lain atau suatu korporasi;

4. Unsur yang dapat merugikan keuangan negara atau perekonomian;

5. Unsur mereka yang melakukan, yang menyuruh melakukan dan yang turut serta melakukan tindak pidana itu;

\section{Ad. 1. Unsur Setiap Orang;}

Bahwa pengertian setiap orang adalah siapa saja. Siapa saja dapat juga diartikan sebagai barang siapa dan dalam ajaran hukum pidana adalah menunjuk subyek dari strafbaarfeit (perbuatan pidana), sehingga yang dapat dianggap sebagai subyek dari strafbaarfeit tersebut hanya natuurlijk persoon (manusia hidup). Bahwa pelaku dari tindak pidana di dalam Pasal 2 ayat (1) jo. Pasal 18 Undang-Undang Nomor 20 Tahun 2001 jo. Pasal 55 KUHP ayat (1) ke-1 KUHP telah ditentukan "setiap orang" sesuai dengan ketentuan Pasal 1 angka 3 UndangUndang Nomor 20 Tahun 2001 yang dimaksud setiap orang adalah orang perorangan atau korporasi.

Bahwa dari fakta-fakta hukum Terdakwa mengaku bernama Dedi Hermawan merupakan orang yang bertanggung jawab atas kegiatan tersebut dan saksi-saksi juga membenarkan identitas Terdakwa adalah benar sebagai orang yang dapat dimintai pertanggungjawaban pidana, dikarenakan tidak dapat membebaskan atau melepaskan Terdakwa dari tuntutan pidana. Dengan demikian, unsur ini telah terpenuhi secara sah dan meyakinkan menurut hukum.

\section{Ad. 2. Unsur Secara Melawan Hukum;}

Bahwa dalam penjelasan Pasal 2 ayat (1) Undang-Undang Nomor 20 Tahun 2001 menyebutkan bahwa yang dimaksud dengan "secara melawan hukum" mencakup perbuatan Pertanggungjawaban Pidana Direktur Perseroan Terbatas Dalam Tindak Pidana Korupsi Proyek Terbatas Dalam Tindak Pidana Korupsi Proyek Pembangunan Rumah Sakit (Studi Putusan No. 15/Pid.Sus- 
melawan hukum dalam arti formil maupun dalam arti materiil, yakni meskipun perbuatan tersebut tidak diatur dalam peraturan perundang-undangan. Namun, apabila perbuatan tersebut kehidupan sosial dalam masyarakat, maka perbuatan tersebut dapat dipidana.

1) Bahwa penyimpangan dalam pemilihan penyedia jasa berupa:

a) Adanya dugaan persaingan tidak sehat dalam proses lelang.

b) Surat keterangan dukungan Bank untuk PT. Care Indonusa tidak diakui Bank Sumut.

2) Penyimpangan dalam pelaksanaan kontrak. Hasil pemeriksaan atas dalam pelaksanaan kontrak, yaitu:

a) Penyusunan Change Contract Order (CCO) tidak didukung dengan hasil pengukuran/perhitungan teknik dan usulan dari penyedia jasa.

b) Berita acara pembayaran dan berita acara pemeriksaan prestasi pekerjaan untuk pembayaran termin 60\% tanggal 18 Desember 2015 dibuat tidak sesuai dengan kondisi senyatanya; dan

c) Volume pekerjaan terpasang tidak sesuai kontrak.

\section{Ad. 3. Unsur Memperkaya Diri Sendiri, Orang Lain, atau Suatu Korporasi;}

Bahwa yang dimaksudkan dalam unsur ini adalah timbulnya niat dari pelaku untuk melakukan perbuatan tersebut demi kepentingan diri sendiri atau orang lain sehingga dapat merubah kondisi kehidupannya, dengan memperhatikan perumusan ketentuan tentang tindak pidana korupsi seperti yang terdapat dalam Pasal 2 ayat (1), dapat diketahui bahwa unsur "melawan hukum" dari ketentuan tentang tindak pidana korupsi tersebut merupakan sarana untuk melakukan perbuatan memperkaya diri sendiri atau orang lain atau korporasi.

Bahwa Terdakwa telah melakukan pencairan terhadap kegiatan ini sebanyak 2 (dua) kali yakni:

a. Berita acara pembayaran termin muka 20\% No. 900/396/PPSPRSPU/APBD/2015 dari nilai kontrak.

b. Berita acara pembayaran termin I dan II (60\%) uang muka $20 \%$ pencairan pada saat progress pekerjaan $60 \%$ dan dasar pencairan adalah sudah mencapai fisik $70 \%$ yang dituangkan dalam laporan kemajuan pelaksanaan pekerjaan yakni 7o,o1\%.

\section{Ad. 4. Unsur Yang Dapat Merugikan Keuangan Negara atau Perekonomian Negara;}

Bahwa kata dapat sebelum frasa "merugikan keuangan negara atau perekonomian negara" menunjukan bahwa tindak pidana korupsi merupakan delik formil yaitu adanya tindak pidana korupsi cukup dengan timbulnya akibat, dengan demikian dari rumusan tersebut kerugian negara tidaklah mutlak/harus telah terjadi. Namun, juga dapat dikenakan terhadap kerugian negara yang belum terjadi tetapi perbuatan melawan hukum yang dilakukan tersebut sudah berpotensi akan dapat menimbulkan kerugian negara atau perekonomian negara.

Bahwa penyimpangan-penyimpangan yang disebabkan oleh pihak-pihak tersebut mengakibatkan terjadinya kerugian negara sebesar Rp. 1.013.877.289.19,- (satu miliar tiga belas juta delapan ratus tujuh puluh tujuh ribu dua ratus delapan puluh sembilan koma sembilan belas rupiah). Dalam hal ini keuangan pemerintah kota Tanjung Balai, dengan demikian unsur ini telah secara sah dan meyakinkan.

Ad. 5. Unsur Mereka Yang Melakukan, Yang Menyuruh Melakukan dan Yang Turut Serta Melakukan Tindak Pidana Itu;

Bahwa jelas makna dari istilah penyertaan (deelneming) ialah dua orang atau lebih yang melakukan tindak pidana atau dengan lain perkataan ada dua orang atau lebih mengambil bagian untuk mewujudkan suatu tindak pidana. Bahwa Terdakwa melakukan permintaan dan penyusunan Change Contract Order (CCO) tidak didukung dengan hasil pengukuran/perhitungan teknik dan usulan dari penyedia jasa. Bahwa Terdakwa tidak 
mengusulkan pengukuran/penghitungan teknik sebagai dasar CCO atas kontrak dan PPK menyetujui dan menandatangani CCO yang tidak memiliki pengukuran/perhitungan teknik dan usulan dari penyedia jasa.

Bahwa Terdakwa mengajukan pembayaran termin $60 \%$ atas kemajuan pekerjaan pada tanggal 18 Desember 2015, meskipun volume pekerjaan terpasang tidak sesuai dengan kondisi senyatanya dan PPK kemudian menerbitkan surat perintah membayar (SPM) dalam rangka pembayaran termin 60\% tanggal 18 Desember 2015 kepada Sdr. Dedi Hermawan (Direktur PT. Care Indonusa). Bahwa Terdakwa belum menyerahkan hasil pekerjaan kepada pihak Dinas PU kota Tanjung Balai sebagai pengguna barang/jasa atau owner; dan Bahwa Terdakwa tidak melaksanakan pekerjaan sesuai volume yang diatur dalam kontrak.

Terhadap penjelasan diatas penulis sependapat dengan dasar pertimbangan Hakim yang memberikan beberapa pertimbangan sebelum menjatuhkan putusan kepada terdakwa. Salah satu yang menjadi pertimbangannya ialah hal-hal yang memberatkan bagi terdakwa yang menjadi dasar pertimbangan Hakim dalam menjatuhkan hukuman adalah terdakwa tidak mendukung program pemerintah dalam memberantas tindak pidana korupsi, yakni karena telah terjadi pelanggaran terhadap Pasal 2 ayat (1) jo. Pasal 18 Undang-Undang Nomor 20 Tahun 2001 tentang Pemberantasan Tindak Pidana Korupsi yang unsurnya yakni setiap orang, secara melawan hukum, memperkaya diri sendiri, orang lain atau suatu korporasi, yang dapat merugikan keuangan negara atau perekonomian negara, mereka yang menjalankan, yang menyuruh melakukan, dan yang turut serta melakukan tindak pidana itu. Disisi lain, hal yang meringankan bagi terdakwa selama proses persidangan adalah terdakwa belum pernah di hukum dan terdakwa berperilaku sopan, jujur di persidangan serta terdakwa memiliki tanggungan keluarga. Disamping itu, penulis juga berpandangan bahwa dasar pertimbangan Hakim tersebut sejalan dengan teori pertanggungjawaban Direktur Perseroan Terbatas yakni teori fiduciary duty yang lahir dari suatu hubungan fidusia. Tidak semua orang bisa mendapatkan suatu kewajiban fidusia, kecuali orang itu mempunyai kemampuan fidusia, yaitu kemampuan untuk memegang dan melaksanakan amanah dari pihak lain berkenan dengan suatu hal, mengurus, dan menjalankannya, untuk kepentingan si pemberi amanah. Sehingga bila melihat kepada kasus Direktur PT. Care Indonusa An. Dedi Hermawan, maka pertanggungjawaban hanya dimintakan kepada Direktur sesuai dengan teori fiduciary duty diatas.

\section{Putusan Hakim}

Dalam Pasal 1 ayat (1) KUHAP menegaskan putusan pengadilan adalah pernyataan Hakim yang diucapkan dalam sidang pengadilan terbuka, yang dapat berupa pemidanaan atau bebas atau lepas dari segala tuntutan hukum dalam hal serta menurut cara yang diatur dalam undang-undang ini. Tugas Hakim adalah mengambil atau menjatuhkan keputusan yang mempunyai akibat hukum bagi pihak lain. Ia tidak dapat menolak menjatuhkan putusan apabila perkaranya sudah mulai diperiksa. Bahkan perkara yang telah diajukan kepadanya tetapi belum diperiksa tidak berwenang ia menolak. ${ }^{9}$

Sebelum Majelis Hakim menjatuhkan hukuman kepada Terdakwa atas perkara ini, maka Majelis Hakim juga mempunyai pertimbangan-pertimbangan sebelumnya. Salah satu yang menjadi dasar pertimbangan Hakim dalam menjatuhkan hukuman yaitu tuntutan dari Penuntut Umum dan hal-hal yang meringankan serta hal-hal yang memberatkan.

Sesuai dengan dakwaan dan tuntutan dari Jaksa Penuntut Umum maka dalam Putusan Nomor 15/Pid.Sus.TPK/2018/PN.Mdn. Terdakwa Dedi Hermawan, terbukti secara sah dan meyakinkan bersalah melakukan tindak pidana "korupsi" sebagaimana dakwaan primair.

\footnotetext{
${ }^{9}$ R. M. Sudikno Mertokusumo dan A. Pitlo, Bab-Bab Tentang Penemuan Hukum, Yogyakarta, Citra Aditya Bakti, 1993, hlm. 40. Pertanggungjawaban Pidana Direktur Perseroan Terbatas Dalam Tindak Pidana Korupsi Proyek Terbatas Dalam Tindak Pidana Korupsi Proyek Pembangunan Rumah Sakit (Studi Putusan No. 15/Pid.SusTPK/2018/PN.Mdn) 
Menjatuhkan pidana kepada Terdakwa dengan pidana penjara selama 5 (lima) tahun dan 6 (enam) bulan dan denda sejumlah Rp. 200.00o.ooo,- (dua ratus juta rupiah) dengan pidana kurungan selama 4 (empat) bulan. Menghukum Terdakwa untuk membayar uang pengganti sebesar Rp. 1.013.887.298.19,-- (satu miliar tiga belas juta delapan ratus tujuh puluh tujuh ribu dua ratus sembilan puluh delapan ribu sembilan belas rupiah), jika Terdakwa tidak sanggup membayar uang pengganti paling lama dalam waktu 1 (satu) bulan sesudah putusan pengadilan yang berkekuatan hukum tetap, maka harta bendanya dapat disita oleh Jaksa dan dilelang untuk menutupi uang pengganti tersebut, dalam hal Terdakwa tidak mempunyai harta benda yang mencukupi untuk membayar uang pengganti, maka akan diganti dengan pidana penjara selama 1 (satu) tahun penjara.

Penulis sependapat dengan putusan Hakim yang telah dijatuhkan terhadap terdakwa berupa pidana penjara selama 5 (lima) tahun dan 6 (enam) bulan, karena perbuatan Terdakwa selaku Direktur PT. Care Indonusa telah terbukti secara sah dan meyakinkan melakukan tindak pidana korupsi pembangunan rumah sakit type $C$ kota Tanjung Balai, dimana perbuatan tersebut berhubungan dengan jabatannya dan bertentangan dengan kewajibannya selaku Direktur PT. Care Indonusa serta dilakukan secara melawan hukum untuk memperkaya diri sendiri, orang lain atau korporasi, atas perbuatannya tersebut telah merugikan keuangan negara sebesar Rp. 1.013.877.289.19,- (satu miliar tiga belas juta delapan ratus tujuh puluh tujuh ribu dua ratus delapan puluh sembilan koma sembilan belas rupiah) sehingga Direktur An. Dedi Hermawan dapat dipidana karena mampu bertanggung jawab sebab tidak ditemukannya alasan pemaaf (schuldausshliesungsgrund). Sebaliknya terhadap beberapa putusan Hakim diatas penulis tidak setuju dengan putusan denda sejumlah Rp. 200.000.00o,- (dua ratus juta rupiah) dengan pidana kurungan selama 4 (empat) bulan. Menghukum Terdakwa untuk membayar uang pengganti sebesar Rp. 1.013.887.298.19,-- (satu miliar tiga belas juta delapan ratus tujuh puluh tujuh ribu dua ratus sembilan puluh delapan ribu sembilan belas rupiah), jika Terdakwa tidak sanggup membayar uang pengganti paling lama dalam waktu 1 (satu) bulan sesudah putusan pengadilan yang berkekuatan hukum tetap, maka harta bendanya dapat disita oleh Jaksa dan dilelang untuk menutupi uang pengganti tersebut, dalam hal Terdakwa tidak mempunyai harta benda yang mencukupi untuk membayar uang pengganti, maka akan diganti dengan pidana penjara selama 1 (satu) tahun penjara. Penulis mendiskripsikan bahwa Direktur bisa saja tidak membayar denda dengan memilih beberapa bulan kurungan sehingga atas putusan ini dapat membuat tidak dapat dipulangkannya kerugian negara yang nominalnya terbilang tidak sedikit karena pada hakikatnya tindak pidana korupsi adalah kejahatan luar biasa yang dampaknya luar biasa maka sepatutnya penanganannya membutuhkan penanganan yang luar biasa pula.

Sejalan dengan penjelasan diatas, bila melihat kepada teori pertanggungjawaban pidana Direktur Perseroan Terbatas yakni teori fiduciary duty yang lahir dari suatu hubungan fidusia. Tidak semua orang bisa mendapatkan suatu kewajiban fidusia, kecuali orang itu mempunyai kemampuan fidusia, yaitu kemampuan untuk memegang dan melaksanakan amanah dari pihak lain berkenan dengan suatu hal, mengurus, dan menjalankannya, untuk kepentingan si pemberi amanah. Sehingga melalui ikatan untuk memegang dan melaksanakan amanah kepercayaan dari pihak lain tersebut dan Direktur juga diharuskan untuk menjalankan perseroan dengan itikad baik sesuai ketentuan anggaran dasar perusahaan. Bilamana terdapat pelanggaran yang hanya dilakukan oleh Direktur dan perseroan tidak memiliki "kesalahan" maka pertanggungjawaban hanyalah dimintakan terhadap Direktur perseroan karena dengan dasar hubungan fidusia tersebut dan Direktur selaku persona standi in judicio atau subyek hukum mandiri. Sehingga tepatlah Putusan Hakim Pengadilan Negeri Medan terhadap Direktur PT. Care Indonusa karena pada kasus tindak pidana korupsi tersebut dilakukan oleh 
Direktur dan perseroan tidak terlibat di dalamnya sebab uang hasil korupsi tersebut tidak masuk ke dalam rekening perseroan dan perseroan sendiri pun tidak ikut menikmati uang hasil tindak pidana korupsi tersebut. Melainkan uang hasil tindak pidana korupsi tersebut masuk kedalam rekening milik Direktur PT. Care Indonusa An. Dedi Hermawan sehingga atas hal tersebut, terdapatnya "kesalahan" sebagai dasar dapat dimintakannya pertanggugjawaban pidana (geen straf zonder schuld).

Penulis juga berpandangan kepada kedudukan direksi sebagai wakil perseroan yang pengangkatannya dilakukan oleh RUPS harus dipandang sebagai mandat kepada direksi untuk oversee management and return profits bagi pemegang saham. Karena antara lain hal inilah, maka direksi dianggap sebagai organ perseroan yang penting (primary organ). Tugas dan kewajiban serta wewenang direksi suatu perseroan menurut Undang-Undang Nomor 40 Tahun 2007 tentang Perseroan Terbatas dalam Pasal 92 ayat (1) yang menyatakan "direksi menjalankan pengurusan perseroan untuk kepentingan perseroan dan sesuai dengan maksud dan tujuan perseroan". Apabila tugas dan kewajiban itu dilakukan atau wewenang jabatan itu telah disalahgunakan, akan membawa konsekuensi terhadap pejabat/pengurus yang melalaikannya itu. Pejabat/pengurus tersebut harus bertanggung jawab atas kelalaiannya itu atau penyalahgunaan kewenangannya itu. Demikian pula untuk jabatan anggota Direksi suatu perseroan.

\section{D.Kesimpulan Kesimpulan}

Berdasarkan hasil penulisan penelitian ini dapat disimpulkan, yang menjadi pertanggungjawaban pidana Direktur Perseroan Terbatas dalam tindak pidana korupsi proyek pembangunan rumah sakit berdasarkan Studi Putusan Nomor 15/Pid.Sus-TPK/2018/PN.Mdn adalah:

Bahwa berdasarkan perbuatan dan kesalahan Direktur Perseroan Terbatas tersebut telah memenuhi syarat pertanggungjawaban pidana sebagai dasar dapat dimintakannya pertanggungjawaban pidana kepada pelaku. Adapun syarat pertanggungjawaban pidana yang telah terpenuhi dari tindak pidana korupsi yang dilakukan oleh Dedi Hermawan adalah adanya suatu tindak pidana yang dilakukan oleh pembuat yakni berupa tindak pidana korupsi yang dilakukan untuk memperkaya diri sendiri atau orang lain secara melawan hukum yang mengakibatkan kerugian negara sebesar Rp.1.013.887.298.19,-- (satu miliar tiga belas juta delapan ratus tujuh puluh tujuh ribu dua ratus sembilan puluh delapan ribu sembilan belas rupiah), adanya unsur kesalahan berupa kesengajaan atau kealpaan, bahwa perbuatan Direktur Perseroan Terbatas dalam Putusan No. 15/Pid.Sus-TPK/2018/PN.Mdn dilakukan secara sengaja dalam arti bahwa perbuatan Direktur tersebut dilakukan secara sadar dan telah melanggar unsur Pasal 2 ayat (1) jo. Pasal 18 ayat (1) Undang-Undang Nomor 20 Tahun 2001 tentang Pemberantasan Tindak Pidana Korupsi jo. Pasal 55 ayat (1) ke-1 KUHP, adanya pembuat yang mampu bertanggung jawab, bahwa Direktur An. Dedi Hermawan terkualifikasi dapat mempertanggungjawabkan perbuatannya dikarenakan ia seorang yang cakap dalam hukum, dan syarat terakhir adalah tidak adanya alasan pemaaf maupun alasan pembenar dalam perbuatan Direktur Dedi Hermawan tersebut, yang dapat menghapuskan kesalahan Direktur Dedi Hermawan. Disisi lain, bila melihat teori pertanggungjawaban pidana Direktur yakni fiduciary duty yang lahir dari suatu hubungan fidusia. Tidak semua orang bisa mendapatkan suatu kewajiban fidusia, kecuali orang itu mempunyai kemampuan fidusia, yaitu kemampuan untuk memegang dan melaksanakan amanah dari pihak lain berkenan dengan suatu hal, 
mengurus dan menjalankannya, untuk kepentingan si pemberi amanah. Oleh karena itu, Direktur sepatutnya berhak dan berwenang untuk bertindak atas nama dan untuk kepentingan perseroan dalam batas-batas yang diijinkan oleh peraturan perundang-undangan dan anggaran dasar perusahaan. Serta mengedepankan prinsip good corporate governance yakni pengelolaan perusahaan yang mengedepankan etika dalam berusaha. Sehingga atas dasar syarat pertanggungjawaban pidana dan teori pertanggungjawaban Direktur maka menjadi suatu dasar kuat dapat dimintakannya pertanggungjawaban pidana terhadap Direktur Perseroan Terbatas sebagai awal dari dakwaan primair dari Jaksa Penuntut Umum.

\section{Saran}

Diharapkan bila nantinya terdapat revisi dan pembaharuan terhadap Undang-Undang Nomor 20 Tahun 2001 tentang Pemberantasan Tindak Pidana Korupsi sebaiknya memaksimalkan hukuman terhadap perbuatan pelaku tindak pidana korupsi dengan menghilangkan pidana kurungan karena apabila pelaku tidak mampu atau tidak berkeinginan membayar uang denda maka pelaku bisa saja memilih untuk pemberian hukuman kurungan beberapa bulan sehingga uang hasil tindak pidana korupsi yang mengakibatkan kerugian negara tidak dapat dikembalikan kepada negara. Selain itu, klasifikasi kejahatan tindak pidana korupsi sebagai kejahatan luar biasa (extra ordinary crime) yang dampak perbuatannya juga luar biasa terhadap perekonomian negara dan hak-hak sosial masyarakat maka sudah sepatutnya pula pemberantasan dan penanganannya memerlukan upaya yang luar biasa pula.

\section{Daftar Pustaka}

Ali, Mahrus, 2015, Asas-Asas Hukum Pidana Korporasi, Jakarta, Rajawali Pers.

Amrani, Hanafi dan Ali, Mahrus, 2015, Sistem Pertanggungjawaban Pidana Perkembangan dan Penerapan, Jakarta, Rajawali Pers.

Chazawi, Adami, 2002, Pelajaran Huku Pidana Bagian I, Jakarta, Raja Grafindo. . 2017, Hukum Pidana Korupsi di Indonesia, Jakarta, Rajawali Pers.

Danil, H. Elwi, Korupsi Konsep, 2014, Tindak Pidana, dan Pemberantasannya, Jakarta, Rajawali Pers.

Gultom, Maidin, 2018, Suatu Analisis tentang Tindak Pidana Korupsi di Indonesia, Bandung, Refika Aditama.

Hamdan, H. M., 2012, Alasan Penghapus Pidana Teori dan Studi Kasus, Refika Aditama, Bandung.

Hamzah, Andi, 2015, Pemberantasan Korupsi Melalui Hukum Pidana Nasional dan Internasional, Jakarta, Rajawali Pers. . 2017, Hukum Pidana Indonesia, Jakarta, Sinar Grafika.

Harahap, M. Yahya, 2013, Pembaharuan Permasalahan dan Penerapan KUHAP Penyidikan dan Penuntutan, Jakarta, Sinar Grafika. . 2015, Hukum Perseroan Terbatas, Jakarta, Sinar Grafika.

Hartanti, Evi, 2012, Tindak Pidana Korupsi, Jakarta, Sinar Grafika.

Hiariej, Eddy, O.S., 2015, Hukum Pidana, Tangerang Selatan, Universitas Terbuka. . 2016, Prinsip-Prinsip Hukum Pidana, Yogyakarta, Cahaya Atma Pustaka.

Huda, Chairul, 2006, Dari Tiada Pidana Tanpa Kesalahan Menuju Kepada Tiada Pertanggungjawaban Pidana Tanpa Kesalahan, Jakarta, Kencana.

Kasiyanto, H. Agus, 2018, Teori dan Praktik Sistem Peradilan Tipikor Terpadu di Indonesia, Jakarta, Kencana.

Komisi Pemberantasan Korupsi, 2006, Memahami Untuk Membasmi, KPK, Jakarta. 
Jurnal Magister Hukum Program Pascasarjana Universitas HKBP Nommensen

Volume 02 Nomor o1 Januari 2021 Halaman. 103-132 e-ISSN: 2723-164X p-ISSN: 2722-9858

http://ejournal.uhn.ac.id/index.php/opinion

Kristian dan Gunawan, Yopi, 2015, Tindak Pidana Korupsi Kajian terhadap Harmonisasi antara Hukum Nasional dan The United Nations Convention Against Corruption (UNCAC), Bandung, Refika Aditama.

Kristian, 2017, Sistem Pertanggungjawaban Pidana Korporasi Ditinjau dari Berbagai Konvensi Internasional, Bandung, Refika Aditama.

Maramis, Frans, 2012, Hukum Pidana Umum dan Tertulis di Indonesia, Jakarta, Raja Grafindo.

Marzuki, Peter, Mahmud, 2014, Metode Penelitian Hukum, Jakarta, Kencana, Prenanda Media Group.

Mertokusumo, R. M. Sudikno dan Pitlo, A., 1993, Bab-Bab tentang Penemuan Hukum, Yogyakarta, Citra Aditya Bakti.

Muladi dan Priyatno, Dwidja, 2010, Pertanggungjawaban Pidana Korporasi, Jakarta, Kencana.

Mulhadi, 2017, Hukum Perusahaan Bentuk-Bentuk Badan Usaha di Indonesia, Jakarta, Rajawali Pers.

Pangaribuan, Aristo, M.A., et al., 2017, Pengantar Hukum Acara Pidana di Indonesia, Jakarta, Rajawali Pers.

Prasetya, Rudi, 2017, Teori dan Praktik Perseroan Terbatas, Jakarta, Sinar Grafika.

Prasetyo, Teguh, 2010, Hukum Pidana, Jakarta, Raja Grafindo.

Rusianto, Agus, 2016, Tindak Pidana dan Pertanggungjawaban Pidana Tinjauan Kritis Melalui Konsistensi antara Asas, Teori, dan Penerapannya, Jakarta, Kencana.

Sjawie, Hasbullah F., 2015, Pertanggungjawaban Pidana, Korporasi pada Tindak $\quad$ Pidana Korupsi, Jakarta, Kencana.

. 2017, Direksi Perseroan Terbatas Serta Pertanggungjawaban Pidana Korporasi, Jakarta, Kencana.

Sutedi, Adrian, 2015, Buku Pintar Hukum Perseroan Terbatas, Jakarta, Raih Asa Sukses.

\section{Peraturan Perundang-undangan}

Undang-Undang Nomor 20 Tahun 2001 tentang Pemberantasan Tindak Pidana Korupsi Undang-Undang Nomor 40 Tahun 2007 tentang Perseroan Terbatas.

Kitab Undang-Undang Hukum Pidana.

Kitab Undang-Undang Hukum Acara Pidana.

RUU KUHP Tahun 2017.

\section{Internet}

https://antikorupsi.org/sites/default/files/tren_korupsi_2017.pdf. 